\title{
ŚWIAT KOLORÓW LUDZI PALEOLITU JAKO ELEMENT INTERTEKSTUALNOŚCI „OBRAZÓW” W JASKINIACH
}

\author{
PALAEOLITHIC PEOPLE'S WORLD OF COLOURS AS AN \\ ELEMENT OF INTERTEXTUALITY OF „PICTURES” IN CAVES
}

\author{
Danuta Minta-Tworzowska \\ Instytut Archeologii. Uniwersytet im. Adama Mickiewicza w Poznaniu \\ ul. Umultowska 89D, 61-614 Poznań, Polska
}

\begin{abstract}
The article discusses an issue of intertextuality of "pictures" in Palaeolithic art, and colour as its constituent. An important concept in these regards appeared to be that of an open and interdisciplinary approach towards an image, derived from the anthropology of images. In my opinion, essential is an "acting" of an image, based on so called "interimaginal relations". It is legitimate when referring to prehistory, as numerous images reveal interpenetrating traces of other representations. Either consciously or unconsciously, some solutions had been used repeatedly, copying other representations, including selection of colours as a kind of stereotype deeply rooted in cultural memory. In cave "pictures" there were one or two main colours used, rarely three or even four. It has been acknowledged that the most important features of Palaeolithic "pictures" were movement, colour, especially expressed by a contrast of black and red or yellow, and also an illusion. They were also interrelated with a sound. The world of colours of contemporary people was a significant constituent of cultural meanings and of images "acting" in "mediatisation" of important existential contents between past and present.
\end{abstract}

KEY WORDS: Paleolithic art, colour in the prehistory, anthropology of images, intertextuality

\section{ZAGADNIENIA WSTEPNE}

W niniejszym artykule podjęto zagadnienie intertekstualności obrazów sztuki paleolitycznej i koloru jako jej elementu. Rozważając problematykę koloru w odniesieniu do twórczości ludzi pradziejowych, nie sposób patrzeć na kolor innymi oczami niż współczesnej kultury i bez stosowania nowożytnych pojęć. Oczywiście sta- 
ramy się zrozumieć inną kulturę, w tym np. grecką czy rzymską, pradziejową, jednak nadal aktualna jest wątpliwość, na ile jest to możliwe. Najczęściej diagnozujemy, że nasze widzenie świata zostało zdominowane przez znaturalizowany sposób patrzenia na świat oparty na estetyzowaniu lub aktywnym przeoczaniu (często wręcz nieświadomym). Zwłaszcza współczesność stara się przełamywać ten sposób ujmowania rzeczywistości. Chodzi o zrozumienie świata, który dawno przeminął, przez zrozumienie świata naszego i możemy to czynić potocznie albo stosując określone metody. Uważam, że wyznawana niekiedy romantyczna hermeneutyka to tylko złudzenie; nawet „,przeniesieni” do przeszłości nie odnaleźlibyśmy żadnego ,archetypu" znaczenia rzeczy, zdarzeń, procesów. Każde z nich, gdy znajdzie się w świecie, niejako od razu podlega interpretacji w danych kategoriach kulturowych, a więc nie istnieje „moment”, do którego zachowuje swoje ,pierwotne” znaczenie. Dotyczy to również sposobów patrzenia na świat. Zawsze chodzi o zrozumienie miejsca w świecie, wewnętrznych i zewnętrznych przyczyn zachodzących tu i teraz procesów, bezpośrednio dotykających ludzi.

Przykłady zaczerpnęłam ze „sztuki” jaskiń, „obrazów” datowanych na paleolit, zwłaszcza na paleolit górny i schyłkowy. Archeologia najczęściej mówi o „sztuce” występującej w jaskiniach; jest to temat wysoce atrakcyjny, lecz nierozwiązywalny, wręcz w kwestii fundamentalnej - czy jest to sztuka? To tak, jak wspinać się na któryś z najwyższych szczytów świata zimą (np. na Nanga Parbat czy K2). Mimo świadomości, że najpewniej szczytu w takich warunkach nie zdobędziemy, to uznajemy, że warto próbować i to różnymi „drogami”. Takie próby podejmuje archeologia nie od dziś i nie tylko w odniesieniu do malowideł i rytów naskalnych w jaskiniach. Nie zmienia to faktu, że przychodzi się nam mierzyć z ogromnymi wyzwaniami, choć często musimy poprzestać jedynie na formalnym opisie zjawiska. $\mathrm{Na}$ takim opisie nie poprzestawały prace, które można uznać za fundamentalne dla badań nad ,sztuką” paleolitu, takie jak atlas malowideł i rytów naskalnych z paleolitu autorstwa Henri Breuil'a z 1952 roku, w którym autor poczynił pierwsze jej interpretacje (Breuil, 1952). W Polsce zapoczątkował takie studia Włodzimierz Antoniewicz (1957). Nie sposób przecenić kolejnych ujęć i swoistego „wybuchu” zainteresowań sztuką w postaci prac m.in.: Bahn i Renfrew, 2002; Bugaj, 2012; Chippendale i Taçon, 1998; Beltrán, 1998; Garcia Guinea, 2001; Gąssowski, 1996, 2008; Gediga, Mierzwiński, Piotrowski, 2001; Gediga, Piotrowski, 2008; Goodman, 1976; Layton, 1981; Leroi-Gourhan, 1966; Mierzwiński, 2001 i wielu innych. Sztuką pradziejową zajmują się archeolodzy od przeszło 100 lat, starając się przybliżyć do jej istoty oraz sensów kulturowych. Jak pisze Bogusław Gediga (2010, s. 47): „w każdej z tych definicji [sztuki - D. M.-T.] ukazana została jakaś szczególna cecha lub kilka cech sztuki, co jest w dużej mierze rodzajem stałego przybliżania się do określenia tego fenomenu". Wysiłek taki podjął już w 1925 roku Moritz Hoernes w swojej przełomowej pracy, w której starał się zdefiniować sztukę pradziejową, odwołując się do filozofii, do teorii sztuki i stosował je praktycznie w kwestii po- 
czątków ornamentyki, rozwoju ozdób ciała, uwzględniając ogromny materiał z zakresu pradziejów (Gediga, 2010, s. 47). Niektórzy badacze zwracali uwagę na motywy powstawania sztuki tkwiące w sferze wierzeniowej (m.in. Filip, 1974, s. 74; Rozwadowski, 2002, 2003, 2004) albo w świecie idei, choć służyła do opanowywania ówczesnego świata (Kębłowski, 1987, s. 12). Najczęściej jednak uznaje się ją za świadectwo historyczne służące poznaniu różnych aspektów minionej kultury (m.in. Gediga, 2010, s. 48).

W niniejszych rozważaniach istotne są „obrazy” w jaskiniach. Mówienie o obrazach i o obrazowaniu pozwala uniknąc wikłania się w rozważania dotyczące sztuki, co daje nową perspektywę rozważań (np. Minta-Tworzowska, 2011). Nie do końca zgadzam się z historykami sztuki, np. z E. H. Gombrichem (2016, s. 40-42), który uważa, że malowidła $w$ jaskiniach były najczęściej bezładne, rzadko ułożone w kompozycie. Podkreślę raz jeszcze, to co dla obecnego widza-badacza jawi się w taki sposób, jest jedynie interpretacją. Pryzmat takiej, a nie innej kultury bardzo wiele zmienia, niekiedy wszystko. Podkreślę, że z perspektywy mojego odbioru „obrazów” paleolitu mają one ład oraz określony sens i znaczenie.

\section{REFLEKSJA NAD OBRAZEM}

Ponieważ nie toczy się $\mathrm{w}$ archeologii jakaś aktywna dyskusja dotycząca kolorów, to wybór drogi obejmuje osiągnięcia innych dziedzin, zwłaszcza humanistyki. Pewne propozycje $\mathrm{w}$ kwestii rozważań nad kolorem wyszły z neoformalistycznej niemieckiej szkoły „historii kolorystyki”, która skupiała się głównie na malarstwie. Istotne okazały się dwa poglądy na temat obrazu i obrazowania. Pierwszy, tzw. zwrot ikoniczny, nazwany tak w 1994 roku przez Gottfrieda Boehma, który „rewolucję cyfrową" łączy z przełomem w myśleniu o obrazie i dla niego historia nauki to „historia obrazów” (Boehm, 2014). Drugi - zwrot obrazowy, czyli pogląd dotyczący koncepcji antropologii obrazu Hansa Bettinga (2001) o otwartym i interdyscyplinarnym rozumieniu obrazu. H. Belting odnosi się do sztuki i proponuje, aby badając sztukę sprzed ery renesansu, mówić o „sztuce sprzed ery-sztuki”, co pozwala w istocie odejść od rozważań o sztuce na rzecz wypowiedzi nad przeszłym obrazowaniem wizualnym w ogóle, ponieważ człowiek od zarania swojego istnienia stosował obrazowanie. $\mathrm{W}$ tej perspektywie wszelkie formy obrazowania można ujmować jako wizualne formy wyrazu i przedstawiania, bez konieczności wikłania się w próbę odpowiedzi na pytanie, czy to jest ,sztuka” z wszystkimi konsekwencjami wynikającymi z uznawania danych wytworów za sztukę. Taką perspektywę dało podejście interdyscyplinarne, reprezentowane przez $\mathrm{H}$. Beltinga i rozwijane przez innych badaczy reprezentujących często nurt tzw. visual studies. Otworzyły one drogę do dyskusji na temat roli obrazów oraz myślenia obrazowego w kulturze XX i XXI wieku. Co więcej, ów zwrot obrazowy poszerza nasze poznanie wyznaczone przez 
granice języka, a obecnie mówi się o relacji lustrzanej między percepcją a językiem i wszechobecności metafor wizualnych we współczesnym języku. Niektórzy idą jeszcze dalej, twierdząc, że język jest częścią kultury wizualnej (w sensie potocznym „widzę”, znaczy „rozumiem”). Należy się zgodzić, że współcześnie posługujemy się ,językiem” obrazu, który jest równoprawny z tekstowym komunikowaniem. Poglądy te są znaczące dla archeologii i interpretacji jej pradziejowych „obrazów”.

Jednak jak się wydaje, równie istotne znaczenie dla archeologii mają poglądy preferujące ogólniejsze spojrzenie na (zmienną historycznie) problematykę koloru i jego roli, jednak związane z poglądami europejskimi, zwłaszcza Europy Zachodniej. Tylko z takiej perspektywy i przy takich założeniach jest możliwe traktowanie sztuki paleolitu jako szeroko rozumianej rodzącej się tradycji sztuki europejskiej (choć nie w sposób sumaryczny) i zrozumienie w jakimś zakresie ówczesnego świata. Badacze starają się ją rozumieć, poczynając od dziedzictwa klasycznego aż do współczesności, śledząc teorie koloru i ich praktyczne zastosowania przez wieki albo decydując się na brak teorii koloru. Jednak najczęściej te studia omijają temat pradziejów, uważając w najlepszym razie, jak np. E. H. Gombrich (2016, s. 39), że były to „osobliwe początki”, powiązane z magią.

Problem z połączeniem tekstualności z wizualnością „obrazów” paleolitu polega na niemożności porównania języka, określeń wówczas stosowanych czy rodzących się wraz z owymi szczególnymi artefaktami, co wydaje się konieczne przy tak postawionym celu badań. Owe artefakty w postaci malowideł i rytów naskalnych istnieją, jednak nie znamy języka, ,pojęć” ich dotyczących z tak odległej przeszłości, jaką były pradzieje. Mam świadomość, że nie jest to bezpośrednie przełożenie interpretacji językowej na postrzeganie obrazów, w tym kolorów, ponieważ kolor stanowi wielowartościowe zjawisko, ale zapewne bardziej adekwatne niż stosowanie dzisiejszej terminologii dotyczącej barw, kolorów. Dlatego dziś uważamy, że nasze poznanie składa się z dwóch zespolonych elementów - obrazowego i pojęciowego. Myśleniu archaicznemu przypisywane jest niekiedy wyłącznie myślenie obrazowe. Jednak, jak się wydaje, człowiek archaiczny ma te same zdolności kognitywne, co nowożytny, a także włączał zdolności emocjonalne.

\section{DZIAŁANIE OBRAZU POPRZEZ INTERTEKSTUALNOŚĆ}

Moim zdaniem najważniejsze jest „działanie” obrazu. Odnosi się to zarówno do czasów paleolitu, jak i współczesnych. Ale aby to było możliwe, musimy założyć istnienie „Związków międzyobrazowych”, co nie jest trudne, ponieważ wiele obrazów ujawnia przenikające się ślady innych obrazów. Zwraca się na to uwagę zwłaszcza w historii sztuki, i tak np. Stanisław Czekalski (2006, s. 44) rozważa malarstwo w aspekcie intertekstualności. Co więcej, należy zgodzić się z tymi poglądami, według których każdy obraz można zrozumieć bez odwoływania się do inten- 
cji artysty, a co stanowi wyjście z impasu rozważań na temat twórcy „obrazów” w jaskiniach czy na otwartych skałach itp. Ponieważ obrazy nawiązują do pewnej obrazowej tradycji, przejawiającej się w podobnych malarskich przedstawieniach, choć jednocześnie różnią się od nich. Każdy z paleolitycznych malarzy, aby być zrozumiałym, musiał powtórzyć świadomie lub nieświadomie pewne rozwiązania $\mathrm{z}$ innych malowideł. Możliwy jest również taki scenariusz, że rozpoznajemy w danym obrazie podobieństwo i związki z innymi obrazami, których dany twórca nigdy nie widział. Nie rozstrzygniemy, czy wynika to z naszej interpretacji malowideł, jako pewnej spójnej całości, z naszej pamięci wizualnej, choć musimy ją w końcu rozbić na sekwencje czasowe, czy ze świadomego zamysłu autora. Może to stanowić również efekt pewnych podświadomych czynników wynikających z jakiejś gry obrazowej, o takim, a nie innym charakterze w ówczesnym świecie.

Starając się nakreślić rolę pradziejowego autora, tak jak ją rozumiem, odwołam się do idei Rolanda Barthes'a (1999a), który zastosował teorię intertekstualności do analizy dzieła literackiego, a także pewne jej zasadnicze założenia do malarstwa. Najogólniej idea Barthes'a sprowadza się do tezy, że tak jak tekst nie przedstawia swojej autonomicznej intencji autora, tak dzieło malarskie również tego nie czyni. Tak jak autor tekstu jest już ,złożonym słownikiem, którego słowa można zrozumieć poprzez inne słowa i tak w nieskończoność" (Barthes, 1999a, s. 248), czyli autor jest naznaczony innymi tekstami, które pochodzą $\mathrm{z}$,nieskończenie wielu zakątków kultury”, a które „przepisuje”, zmienia „charakter pisma” (ibidem, s. 250). Podobnie jest $\mathrm{z}$ odbiorcą tekstu; również on został uformowany przez inne interpretacje. Ani autor, ani odbiorca nie są zewnętrzni wobec tekstu; razem tkwią w języku, czyli wewnątrz tekstu. Tekst nie odsyła do jakiejś głębi, do prawdziwych znaczeń; stanowi efekt odniesień do innych tekstów, kodów określanych przez kulturę, przez to, co ,już zobaczone, już przeczytane” (Barthes, 1999b, s. 55).

Eksponuje się tu rolę stereotypu, który można odnieść do malarstwa, stereotypu tkwiącego głęboko w pamięci kulturowej i w związku z tym uchodzącego za coś oczywistego, pochodzącego z samego życia, a nie z czegoś przed nim. Niejako zapomina się, że dany obraz miał swój pierwowzór; fakt ten ginie w wielości podobnych przedstawień jako poprzedzających czy warunkujących jego powstanie. Tym samym następuje zatarcie genealogii tekstu czy obrazu, przez co wywołuje on podobieństwo do prawdy jako „naturalny” obraz rzeczywistości. Ta nieświadomość międzytekstowych czy międzyobrazowych związków powoduje ową mimetyczność efektów. Tworzy to intertekstualny poziom dla autora i odbiorcy. Dlatego za Charlsem Peirce'm (1997, s. 118) uważam, że „Znaczenie, które dowolny znak ma dla kogokolwiek, polega na sposobie reagowania wobec owego znaku". Dlatego znaczenie nie należy do przeszłości i nie polega na poszukiwaniu „źródłowego” znaczenia przedmiotów, obrazów, ale należy do przyszłości, czyli np. do mojej interpretacji. Dlaczego? Ch. Pierce w pracy Jak uczynić nasze myśli jasnymi, uważa że „Jedyną funkcją myślenia jest wytwarzanie przekonań” (Pierce, 1965; Buczyńska- 
-Garewicz, 1965, s. 77). W gruncie rzeczy nigdy nie chodzi o to ,jak naprawdę było", tylko o to, do czego zdołano nas albo my innych przekonać. Przyjmuję metodę analizy opartej na poszukiwaniu podobieństwa, zbieżności, analogii obrazu x do obrazu y. Odpowiada to idei znaku ikonicznego Ch. Peirce'a, zgodnie z którym obraz ,znaczy” tylko to, co przypomina swoim odbiorcom i do czego jest podobny w ich przekonaniu (Buczyńska-Garewicz, 1994, s. 66).

Wydaje się, że już wówczas, w pradziejowym, paleolitycznym świecie ważny był odbiorca, jego emocje, przeżywanie, a nie tylko samo dzieło. Można to odnieść do dokończonych „obrazów” z jaskiń, starannych, złożonych, operujących kolorem, kontrastem, powtarzalnością, a za tym wszystkim kryjących jakąś tajemnicę, choć zapewne miały również się podobać czy wywołać przyjemne emocje u odbiorcy. Obraz jest pewnym fenomenem wizualnym, stanem połączenia między tym, co jest, a tym, czego nie widać lub czego realnie nie ma. Malowane ściany mogły być, poprzez grę elementów, dziełem mocno docierającym do tego, który na nie patrzył, oglądał, dotykał. Dlatego uważam, że owa zmysłowa podstawa odbioru „obrazów” była bardzo istotna, wręcz kluczowa. Odkrywane pewne powtarzalności form, łączenia kolorów są lepiej wytłumaczalne w taki zmysłowy sposób niż poszukiwanie jakichś niezwykłych cech umysłowości ludzkiej. To przedmiot, rzecz, obraz mają być przyjemne dla oka. Od estetycznych walorów, czyli zwrócenia uwagi na podobanie się, na zachwycanie (co eksponuje psychologia percepcji), nie uciekniemy. Obraz, który miałby budować złudzenie głębi, realnego zwierzęcia i zawierać jakąś opowieść lub być wprowadzeniem do dyskursu społecznego - to perspektywa stanowiąca pewną inspirację dla niniejszych rozważań. Mieści się to w zasadniczej idei, że obraz musi ,działać”.

Niewątpliwym pozytywem zajmowania się „obrazami” paleolitu jest to, że archeolodzy mieli i często mają (jeśli nie wyłączono obecnie tych jaskiń z „obiegu”) możliwość oglądania tych dzieł na ścianach jaskiń, a więc w stanie oryginalnym. To niewątpliwa przewaga nad wielością dzieł sztuki, które oglądamy w muzeach, w gablotach sztucznie dla nich stworzonych, a więc w ,nienaturalnym” dla nich kontekście. Oprócz tego, nie do przecenienia pozytywu, istnieją mankamenty. Najważniejszy z nich to ten, że nie dotrzemy do komentarzy tych dzieł we współczesnym im kontekście, świecie. Jednak idea owej pamięci wizualnej, jak się wydaje, stanowi klucz do ich zrozumienia.

\section{KOLOR, HARMONIA KOLORÓW I JEJ ZNACZENIE}

Truizmem jest stwierdzenie, że kolor jest nieodłącznym elementem naszego życia, choć często nie zdajemy sobie z tego sprawy. Pojawia się wszędzie, towarzyszy nam na każdym kroku, oddziałuje na nas, na nasze samopoczucie, odbieramy go podświadomie. Może być motorem naszego działania lub braku działania. 
Źródłem ogólnej wiedzy na temat znaczenia koloru w kulturze, a także swoistych inspiracji, stały się dla mnie prace zwłaszcza Johna Gage'a, autora książek Kolor i kultura (2008) czy Kolor i znaczenie (2013). Szczególnie idee zawarte w pierwszej z nich stały się takim istotnym źródłem. Sam Autor określił cel swoich dociekań jako trud zrozumienia natury fizycznej i psychologicznej koloru i korzyści płynących z tego rozumienia dla kształtowania naszego środowiska kolorystycznego (Gage, 2008, s. 268). Ktoś może powiedzieć, że Cage zajmuje się czasami, poczynając dopiero od antyku, więc jak zrozumieć pradzieje? Dlatego zamysł Gage'a może służyć jako określający pewne ramy i inspiracje, jednak nie jako gotowe odniesienie. Natomiast uważam, że każdy czas i ludzie z tego czasu mają swój świat kolorów, jak również uważają B. Gediga, D. Łaciak, B. Łydżba-Kopczyńska, M. Markiewicz (2017) w odniesieniu do okresu halsztackiego.

Należy w tym miejscu nadmienić, że niektórzy estetycy (np. B. Berenson czy J. Ruskin) odrzucali kolor i jego głębię istotową, z całym jego symbolicznym znaczeniem. Zwłaszcza uprzedzenia percepcyjne w postrzeganiu koloru zakorzenione są w tradycji klasycystycznej, gdzie przedstawienie postrzegano jako najważniejsze zadanie artysty, a kolor był sprawą drugorzędną; liczyła się technika wykonania, materiały i samo przedstawienie. Jednak to stanowisko mnie nie przekonuje i zamierzam pokazać znaczenie koloru już w głębokich pradziejach. Człowiek od początku swojego istnienia otoczony był „kolorem”, ponieważ nawet lód i śnieg mają wiele barw. Parafrazując Johna Cage'a, kolor ma w sobie dużo więcej, niż okazuje oczom. Podejście J. Crage'a wychodzi z obserwacji świata i analizy naszego doświadczenia koloru, co jest pouczające. Już od czasów Goethego i jego dzieła The Alchemist stało się jasne, że teoria koloru nie ogranicza się jedynie do kilku reguł, lecz stanowi bogaty konglomerat idei z dziedziny fizyki i metafizyki (Gray, 1952).

Zacznijmy od tego, co rozumiemy pod pojęciem koloru? Czy to bodziec wizualny, czy może substancja materialna, którą można formować? Gdy mówimy o kolorze, to wyróżniamy takie cechy jak barwa i nasycenie, a także walor barwy, czyli stopień jasności barwy (Gage, 2008, s. 11). Kolor stanowi podstawowy element twórczości, sztuki, ponieważ za jego pomocą artyści tworzą swoje dzieła, przekazują swoje zamysły i wywołują emocje. Koloru nie sposób oddzielić od rozważań nad historycznym kształtowaniem się rozumienia sztuki, a więc nad owymi „światami” kolorów. Istnieje swoisty język koloru, który mówi bardzo wiele i doznawanie danego koloru mogło być udziałem wielu ludzi, poczynając od ludzi paleolitu, którym towarzyszyło zapewne uczucie spójności koloru w przedstawieniach, a także we wzajemnych relacjach różnych obrazów. Dość powszechnie kolory łączy się z określoną symboliką, ze znaczeniem czy wręcz przekazem nie tylko estetycznym, ale praktycznym. W obrazach - jak się wydaje - użycie koloru było bardzo przemyślane, konkretne, kolory niosły ze sobą dodatkowe treści znaczeniowe i przekazywały to, co trudno było w jakiś inny sposób przedstawić (np. łaska, świętość, ciepło zimno; cechy charakteru, nastroje, idee). Gdy to wszystko sobie uświadomimy, 
wówczas może ogarnąć nas prawdziwa fascynacja tym zjawiskiem, jakim jest kolor. Uzmysławiamy sobie również, że jest to niezwykle obszerny temat do rozważań. Archeologia jest jedynie przysłowiowym ,kamykiem do ogródka”.

Kolorem zajmowali się już starożytni, jak Empedokles, Demokryt, Platon czy Arystoteles. Dla Platona biel to „efekt rozszerzania promienia wysyłanego przez oko w procesie widzenia, a czerń to efekt zwężenia”. Gwałtowniejszy „ogień” daje efekt „oślepienia” [żółty - D. M.-T.], a ogień pośredni - krwistą czerwień. U Platona istnieją cztery ,podstawowe” kolory, ale wymienia też mieszanki tych kolorów. Arystoteles operował szerszą skalą barw, a dokładniej siedmioma barwami, od bieli do czerni, którą to skalę łączył z oktawą muzyczną, a więc wymieniał kolory pośrednie, które, jak twierdził, miały powstawać ze zmieszania białego z czarnym. U niego podstawowe kolory to biel, czerń, złoto. Wynikiem modyfikacji światła przez ciemność miała być czerwień. Najistotniejsze z mojego punktu widzenia są rozważania Arystotelesa dotyczące relatywności odbioru barw, ponieważ pisał, że barwa zmieszana z promieniami światła i cieniami wydaje się inna, niż jest $\mathrm{w}$ istocie (Gage, 2008, s. 13; Arystoteles, 1990). Co bardzo istotne, wskazywał, że przedmioty o określonej barwie inaczej wyglądają w cieniu, w świetle słońca, a inaczej w świetle księżyca czy w promieniach ognia itp., ponieważ światło ma swoją barwę i zmienia barwę tych przedmiotów. Istotny jest też kąt widzenia. To właśnie jest najważniejsze spostrzeżenie, czyli owa relatywność w samym odbiorze barw. Od starożytności mamy jednoznacznie świadomość tego, że ludzkie oko nie jest zdolne do oceny prawdziwej natury rzeczy. Sam status kolorów dla starożytnych był wieloznaczny. Jak pisze J. Gage (2008, s. 15), z jednej strony kolor był „czymś wyłącznie dekoracyjnym i fałszywym", a jednocześnie miał zapewniać malarstwu prawdę i życie. Innymi słowy, miał sprawiać, aby obraz „działał”.

Istotnym zagadnieniem do jakiego dochodzimy to kolor i jego znaczenie w kulturze. Mieszczą się tu odpowiedzi na następujące pytania: Czy malarstwo archaiczne operuje barwami podstawowymi? Czy i jak kształtowała się już w paleolicie idea barw, może barw podstawowych? Jak oni odbierali i dobierali kolory? Jaki był język koloru, czy stosowali dla tych barw jakieś określenia, jakie było rozróżnienie barw, interpretacja kolorów. Jest to próba wyjaśnienia (za: Gage, 2008, s. 79) „dlaczego, mimo że oko ludzkie potrafi rozróżnić miliony niuansów koloru, większość języków koloru [...] zawiera od ośmiu do jedenastu ,podstawowych” terminów”. Gage uważa, że „skłonność do tego, co «podstawowe» była zawsze silniejsza niż rozwój coraz subtelniejszych rozróżnień” (Gage, 2008, s. 79).

Nie możemy zapominać, że nowożytne postrzeganie kolorów wprowadził wiek XVII; w tym czasie miały miejsce najpełniejsze i najdalej sięgające zmiany w europejskim rozumieniu koloru głównie jako zjawiska fizycznego. Wciąż istniał problem kolorów podstawowych i skali kolorów. Ale Izaak Newton sformułował dwie idee, które przetrwały do dzisiaj i którymi się posługujemy: pierwsza mówi, że najlepszą formą wyobrażenia relacji kolorów jest układ kolisty; druga, powiązana z pierwszą - to 
idea komplementarności (Gage, 2008. s. 171). Czy oglądający dzieło mieli wiedzę i kompetencje do jego prawidłowego odbioru, czy rozumieli język znaczeń, znaków, „symboli”? Czy może nie potrzeba było go rozumieć, tylko wiedzieć ,jak to działa”.

Sam J. Gage, zastanawiając się nad harmonią barw, odwołuje się do zjawiska tęczy, będącą notabene przedmiotem zainteresowania wielu artystów, badaczy, ponieważ jest to fenomen fizyczny, pogodowy, ale też kolorystyczny. Tęcza mogła oferować malarzom „,naturalny” klucz do harmonii barw. Jak wszystkie zjawiska na niebie, tęcza i związane z nią przejawy kolorów pryzmatycznych były przedmiotem intensywnych badań astronomów, szamanów wielu kultur i prawie we wszystkich okresach. Tęcza jest jedna i wydaje się taka sama, a jednak od zarania przyciągała uwagę filozofów oraz artystów. Fakt subtelnych przejść kolorów w zarysie tęczy skłonił niektórych teoretyków do uznania jej za modelową harmonię kolorystyczną. W tęczy doszukiwano się znaczenia religijnego, politycznego, mistycznego, kolorystycznego, symbolicznego i artystycznego. Również w „Piśmie Świętym” na temat kolorów jest opis tęczy, którą Bóg umieścił na niebie jako znak przymierza i obietnicy zachowania życia po potopie. Podział tęczy na 7 kolorów jest efektem prac I. Newtona i związany jest z optyką, co ,unicestwia całą poezję tęczy, sprowadzając ją do kolorów pryzmatycznych" - jak wspominał w swoich pismach malarz B. R. Haydon (za: Gage, 2008, s. 107). Toczyły się później debaty na temat liczby kolorów w tęczy; o tym, jakie w ogóle kolory ma tęcza, jak i o tym, które kolory należy uznać za „podstawowe”. E. Delacroix sugerował w odpowiedzi dyskutantom (w swoim niedokończonym Stowniku Sztuk Pięknych), że powinni unikać iluzji uniwersalności i upierać się przy swoim do ostatka (za: Bociek, 2009). Można użyć metafory Gage'a, że często filozofowie, teoretycy kolorów przypominają tych, którzy rozplatają tęczę - ponieważ zimny dotyk filozofii unicestwia niesłychany charakter tęczy; rozplata ją (za: Gage, 2008). O jakimś rozszczepieniu kolorów w odniesieniu do paleolitu możemy mówić w sytuacji, gdy światło przechodziło przez bloki, odłamki lodowe, które mogły działać jak pryzmat. Oczywiście w cieplejszych okresach, gdy padał deszcz, zapewne obserwowano zjawisko tęczy, jednak nie odtwarzano jej niuansów kolorystycznych. Wchodził w grę czynnik „oczu” danej kultury - widzimy to, czego nauczyliśmy się widzieć, co było artykułowane i dostrzegane w danej kulturze, a co nie było świadomie pomijane. Ponadto tęcza mogła funkcjonować w sferze magicznych przekonań, niełączonych z mrokiem jaskini. Kolor mógł być traktowany jako materialna substancja, a nie jako coś ulotnego, ponieważ uzyskiwano go ze złóż mineralnych.

\section{RUCH, KOLOR I ILUZJA W „OBRAZACH” W JASKINIACH}

Przyjrzyjmy się „obrazom” na ścianach grot. Sama przestrzeń jaskini nie jest przestrzenią pewną choćby przez niejednorodność czy skomplikowany układ jaskini. Ta „niepewność” dotyczy również usytuowania zwierząt w tej przestrzeni. Jej re- 
kompensatą są trwałe sylwetki zwierząt, ich formy niekiedy bardzo regularnie rozmieszczone na ścianach, kontury form, również kolor, operowanie cieniem. W obrazie, który naprawdę „działa”, występuje nieskończone powtórzenie tych samych relacji czy wręcz tego samego rodzaju ruchu. Co więc jawi się jako ważne w malarstwie jaskiniowym? Trzy elementy: ruch, kolor oraz iluzja.

\section{Ruch}

Twórcy potrafili tak malować obrazy, aby sprawiały wrażenie ruchu zwierzęcia, czy jego śpiącej pozy. Świadczy to, że nie powinniśmy „obrazów” tłumaczyć wyłącznie w kategoriach praktycznych doświadczeń, obycia w świecie. Uważam, że dany bizon znajduje się w ruchu, a inny został ukazany jako śpiący, ponieważ taka jest konwencja przedstawiania w pierwszym przypadku ruchu, a w drugim snu, np. w Altamirze (ryc. 1). Nie można więc twierdzić, że te przedstawienia znajdują się poza sferą „,sztuki” z tego względu, że widoczna jest już pewna zasada, ,konwencja”, która sytuuje je po stronie „sztuki”. Przedstawienia są podporządkowane wydobyciu

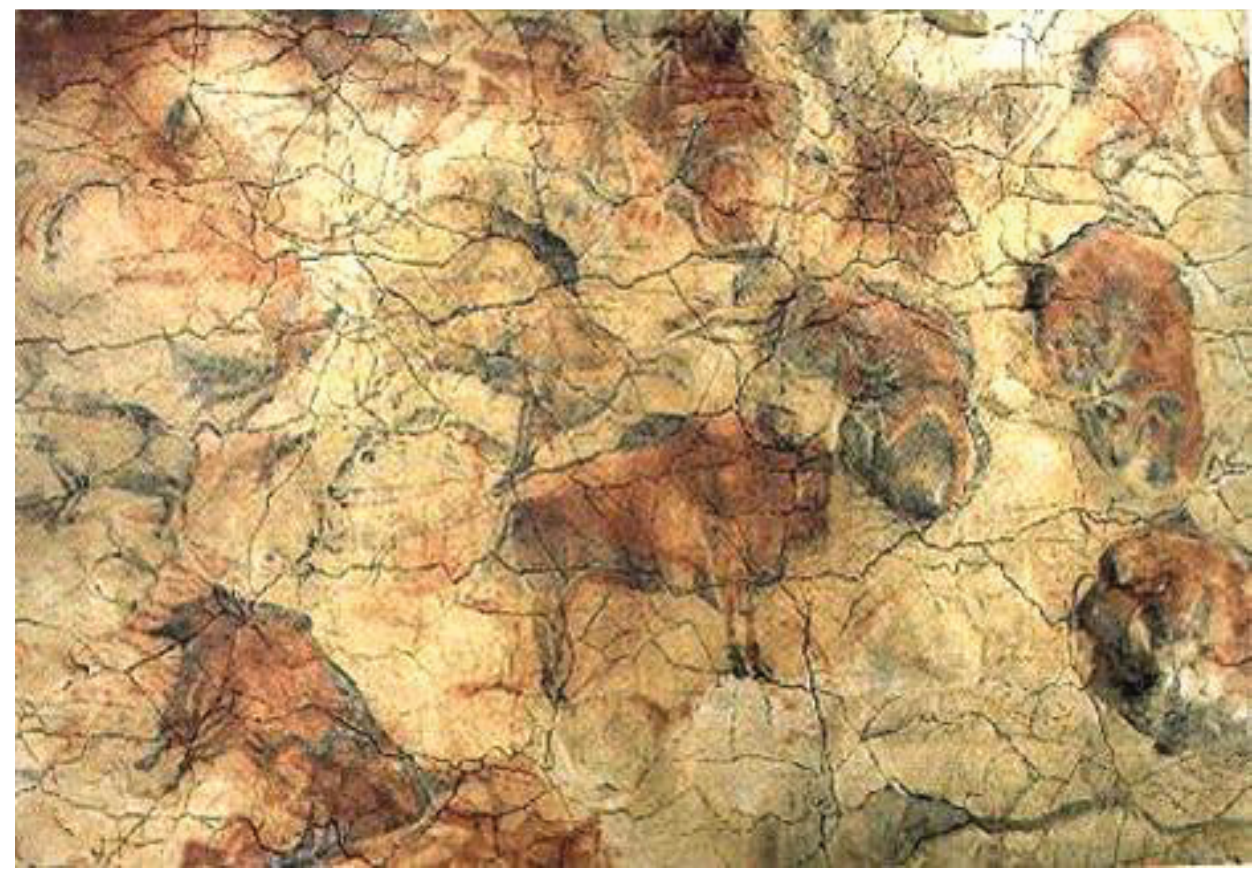

Ryc. 1. Przedstawienia na suficie w grocie Altamira (Beltrán, 1998, s. 12-13; Breuil, 1952, ryc. 3, s. 54-55)

Fig. 1. Paintings on the ceiling in the Altamira cave Altamira (Beltrán, 1998, pp. 12-13; Breuil, 1952, fig. 3, pp. 54-55) 
z całych przedstawień pewnego efektu formalnego. Tzw. perspektywa skręcona: sylwetka zwierzęcia z profilu, a rogi i głowa z przodu, układ nóg sugerujący ruch jest wiele razy powielany w kilkuset jaskiniach, a więc był już wcześniej „,widziany", nawet jeśli twórca sobie tego nie uświadamiał. Poprzez powtarzalność można stwierdzić, że nie pochodzi i nie musi pochodzić ze zdarzeń danych bezpośrednio. Co więcej, przedstawienia zwierząt mają charakter naturalny, a jednak jest coś, co tę naturalność podważa. Zwierzęta nie mają zaznaczonej płci, co jest wysoce ,nienaturalne". Zadziwiająca jest powtarzalność również tej zasady. Wprawdzie przy zwierzętach występują różnego rodzaju znaki, które A. Leroi-Gourhan (1966) interpretuje jako symbole płci (męskie/żeńskie). Ale to tym bardziej uprawomocnia tezę, że przedstawienia na ścianach jaskiń nie są zwykłą wiedzą wynikającą z praktycznych doświadczeń i mimetycznych ich odwzorowań, ,zapisu” na ścianach jaskiń, a tym samym nie jest to mimetyczny zapis ich znaczenia. Dlatego znaczenie tych przedstawień wynika z momentu oddziaływania obrazu na widza (na widza-badacza), który dostrzega podobieństwo między obrazami. Dostrzegał to również twórca i widz pradziejowy, „powtarzając” coś, co było już wcześniej, a co zobaczył np. w sąsiedniej jaskini. Znaczenie nie polega więc na poszukiwaniu czegoś pierwotnego, ale jest ono nabierane (konstruowane) w trakcie odbioru obrazu. Zaświadcza to o istnieniu pamięci wizualnej, która jest „źródłową" wiedzą twórcy, jak i odbiorcy. Widz-badacz odwołuje się również do takiej pamięci wizualnej.

\section{Barwa}

Stosowanie wyrazistych barw sprawiało, że wchodząc do jaskini w świetle lampek czy pochodni, już z pewnej odległości widoczne były mocno wyróżniające się również kolorystycznie kontury czy ciała zwierząt, odciski i obrysy rąk, znaki geometryczne i inne kształty. W niektórych częściach jaskiń, gdzie można było malować w świetle dziennym, np. w jaskini Lascaux, kolory były mniej jaskrawe, wręcz subtelne, nawiązujące niejako do naturalnych barw. Tam, gdzie malowano w sztucznym świetle, w głębokich partiach jaskiń - kolory są jaskrawe, np. w Altamirze bizony są wykonane w czerwonych do purpurowych barwach (ryc. 2). W jaskini Chauvet'a dominuje czerń, ale artysta posłużył się cieniowaniem, wykazując wysoki kunszt - np. głowy koni na panelu (ryc. 3). Wydaje się, że rzadko mieszano kolory; w migoczącym świetle czerń miała w percepcji ludzkiego oka odcienie szarości, grafitu lub matowej czerni, a gdy to zawodziło, to starano się wydobyć efekt kreskowaniem - np. koń z jaskini Niaux (ryc. 4). Dla paleolitycznych twórców istotne było opanowanie linii, ale niemniej użycie wyrazistych barw. Gdy przyglądamy się dziełom dokończonym, to sprawa pigmentu w ich przypadku jest bardzo ważna. Uważam, że w istocie jedynie żywe, czyste kolory mogły sprawić, że „,naturalny” wygląd zwierzęcia na malowidle był w pełni oddany. 


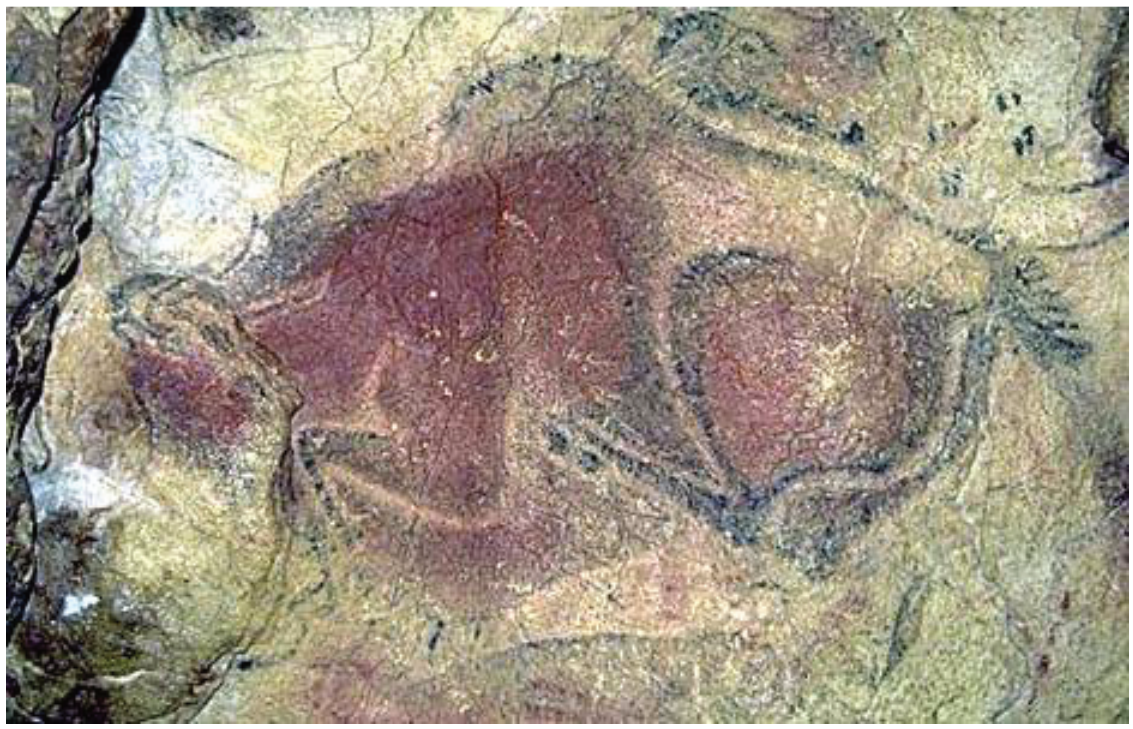

Ryc. 2. Bizon z sufitu w jaskini Altamira (Beltrán, 1998, s. 12-13; Breuil, 1952, ryc. 16, s. 63)

Fig. 2. Bison from the ceiling in the Altamira cave (Beltrán, 1998, pp. 12-13; Breuil, 1952, fig. 16, p. 63)

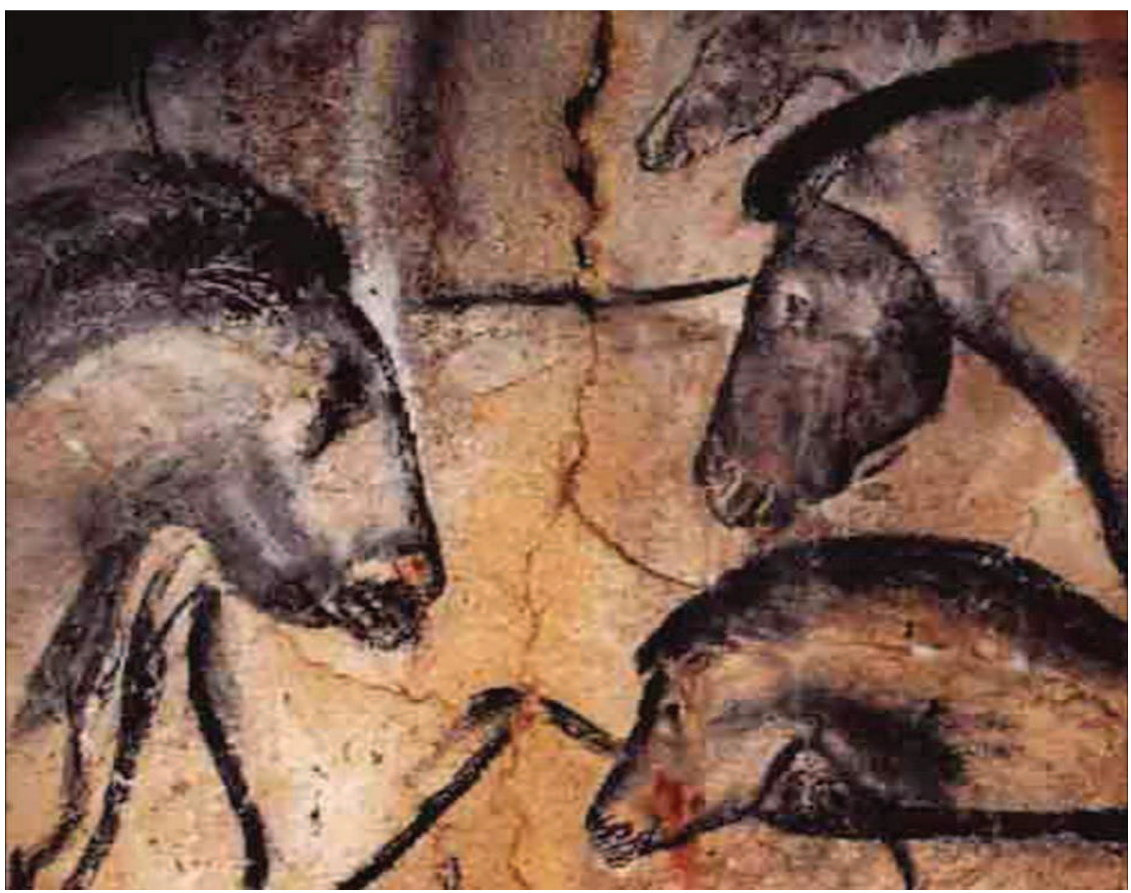

Ryc. 3. Przedstawienia głów koni z jaskini Chavet'a (Chauvet, Deschamps, Hillaire, 1996, ryc. 55, s. 77)

Fig. 3. Paintings of horses heads from the Chavet Cave (Chauvet, Deschamps, Hillaire, 1996, fig. 55, p. 77) 


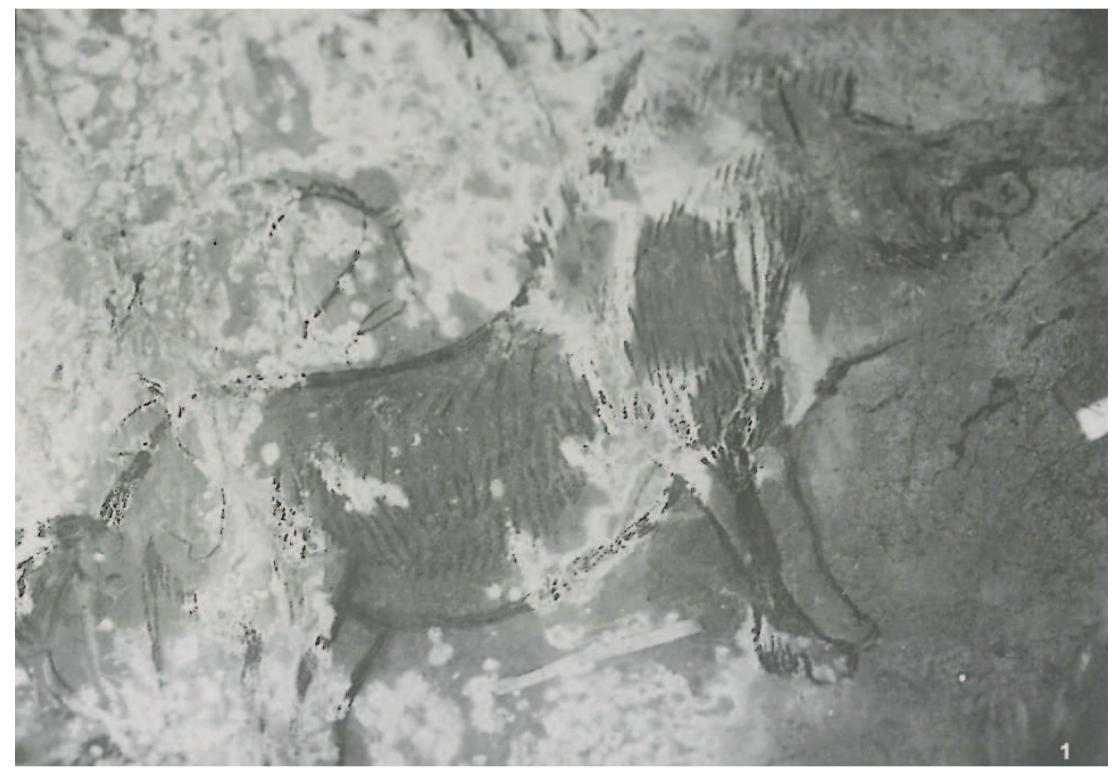

Ryc. 4. Koń z jaskini Niaux w Salon Norie (wygląd przed 1940 r.) (G. Tosello, 2006, ryc. 7, s. 10)

Fig. 4. Horse from Niaux Cave in Salon Norie (appearance before 1940) (G. Tosello, 2006, fig. 7, p. 10)

Jakie rodzaje farb występują w malarstwie jaskiniowym? Artyści paleolitu stosowali kolory, łącząc pigment (kryjącą substancję barwiącą), którym były zazwyczaj nieorganiczne, rozdrobnione minerały, ze spoiwem, w którym się rozprowadzały. Różnica między barwnikiem a pigmentem nie jest wyraźna, jednak przyjmuje się, że barwniki są całkowicie rozpuszczalne w substancji nośnej, w przeciwieństwie do pigmentów, które nie są rozpuszczalne i dlatego wymagają bardzo dużego rozdrobnienia. Biały kolor uzyskiwano z kruszenia i rozcierania skał wapiennych, kaolinu albo był to naturalny kolor ścian, np. w niektórych miejscach w Lascaux. Dla uzyskania koloru stosowano powszechnie ochrę - ochra dawała kolor żółty (Fe2O3*H2O), także czerwony do purpurowego - ochra z dużą zawartością żelaza (Fe2O3), a więc były to naturalne tlenki żelaza, związki nieorganiczne, których zabarwienie wynikało z miejscowego złoża. Również i ją kruszono, zeskrobując warstewki czy proszek krzemiennym narzędziem albo nieduży kawałek surowca rozcierano owalnym kamieniem na płaskim podłożu. Kolor czarny uzyskiwano ze spalonych kości, z węgla drzewnego, zwłaszcza jednak z tlenków manganu. Spoiwem dla farb był tłuszcz zwierzęcy, białko jaj lub woda.

Paletę barw stanowią trzy zasadnicze kolory - żółty, czerwony i czarny. Jednak jest ona bogatsza m.in. ze względu na różnorodność złóż barwników. W istocie składała się z dwunastu barw, które tworzyły trzy odcienie koloru żółtego (od przyciemnionej żółtej barwy poprzez intensywnie żółtą do jasnobeżowej), cztery odcie- 
nie czerwieni - od intensywnej czerwieni i jej niuansów do purpurowej, ale też intensywny brąz i ciemny brąz, a także trzy odcienie czerni - od ciemnoszarej poprzez połyskliwie grafitową do głębokiej matowej czerni.

Jak wykonywano owe „obrazy”? Nanoszono farby na skałę, na podłoże „obrazów", stosując głównie włosie jako pędzle, także ręce (odciski rąk, motywy wykonane palcami) albo rurki z kości puste wewnątrz, służące do wydmuchiwania farby. Funkcję palety mogły pełnić kamienie, na których mieszano farby, a także muszle czy inne pojemniki, w których mieszano i przechowywano farby. W jaskiniach dość często odkrywane są pojemniki na farby, np. w Altamirze do tych celów służyły muszle morskie, w Arcy-sur-Cure czy w jaskini Le Notes odkryto zdobiony pojemnik kościany ze śladami farby. Zostały odkryte również grudki farby na stanowisku Laugerie-Haute, a w niektórych także rodzaj zaostrzonych ołówków. Na terenie zachodnich Węgier odkryto kopalnie ochry i uważa się, że były one czynne już w okresie górnego paleolitu.

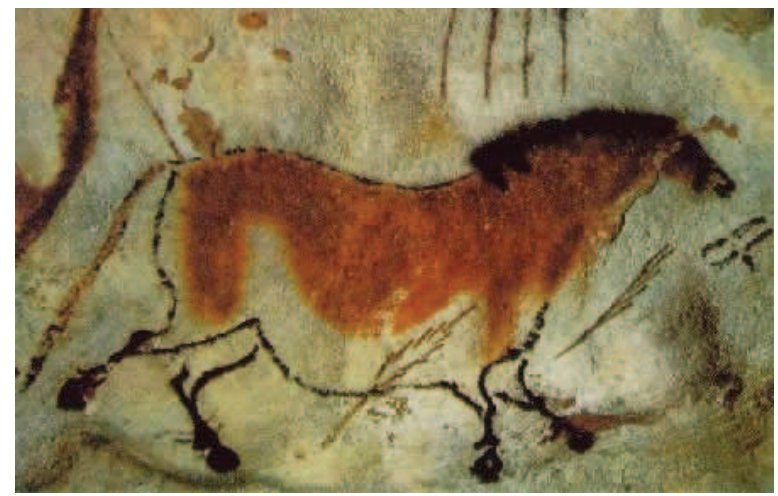

Ryc. 5. Tzw. chiński (żółty) koń z jaskini Lascaux (Breuil, 1952, ryc. 75, s. 109)

Fig. 5. The so-called Chinese (yellow) horse from the Lascaux cave (Breuil, 1952, fig. 75, p. 109)

Na przykładzie jaskini Lascaux można stwierdzić, że podstawowe techniki nanoszenia koloru to wydmuchiwanie farby czy barwnika, rysowanie czarnym „ołówkiem" albo nanoszenie farby pędzlem. Pośrednim środkiem było używanie okrągłego, płasko zakończonego patyka jako swoistej pieczątki. Kontury zwierząt w Lascaux często były wykonywane za pomocą takiej pieczątki. Kropki stawiano gęsto obok siebie, aby tworzyły szeroką ciągłą linię zarysu ciała zwierzęcia. W Lascaux stosowano częściowe rycie konturów zwierzęcia, przykładanie do nich lub brakujących części rytu - szablonu ze skóry w kształcie np. grzbietu jelenia, szyi i grzbietu konia, który przytrzymywano w danym miejscu i wydmuchiwano czarną farbę, a po jego usunięciu uzyskiwano plastyczny zarys grzywy konia czy jego grzbietu. Resztę ciała malowano, przy czym zawsze malowano nogi zwierząt, jak bizony, konie, tury - np. 
tzw. chiński konik (ryc. 5) z panelu o nazwie: Trzy chińskie koniki. Trzy podstawowe kolory w Lascaux to żółty (w sensie jasnego koloru), czerwony i czarny. Zakłada się, że w kolorze ważna jest świetlistość i gęstość; wówczas czerń to brak świetlistości, a czerwień to gęstość, natomiast żółty, zwłaszcza jasny, stanowi przeciwieństwo jednej i drugiej barwy. Słońce ma kolor czerwony, widziany przez mgłę lub przez dym z ognia, a tego doświadczano często. Niekiedy dla wzmocnienia kontrastu stosowano rycie $w$ połączeniu $z$ malowaniem, np. eksponując w ten sposób oczy i chrapy koni w Lascaux. W Lascaux nie stosowano ani koloru zielonego, ani niebieskiego, co także było charakterystyczne w przypadku pozostałych grot. Dodatkowo w Lascaux ,użyto” białej barwy ścian jako koloru, wkomponowując w nią wizerunek tura; w ten sposób zastosowano cztery, a w istocie pięć kolorów: biały, żółty i czarny dla wizerunku tura, a czerwony i brązowy dla nachodzącego na ten wizerunek kolejnego zwierzęcia (ryc. 6). Najczęściej jednak stosowano kolor żółty (jasny) i czarny motyw płynących jeleni wykonanych w postaci szkiców głów czarną farbą, wkomponowanych w jasną skałę (ryc. 7) - albo czerwony i czarny - tzw. walczące bizony (ryc. 8), jak i czerwony, żółty, brunatny, np. kratki w Lascaux (ryc. 9). Należy dodać, że motyw płynących jeleni wykonano, wychodząc od znaku x, który umożliwiał wkomponowanie dla wielu przedstawień równego poroża i zarysu głów jeleni.

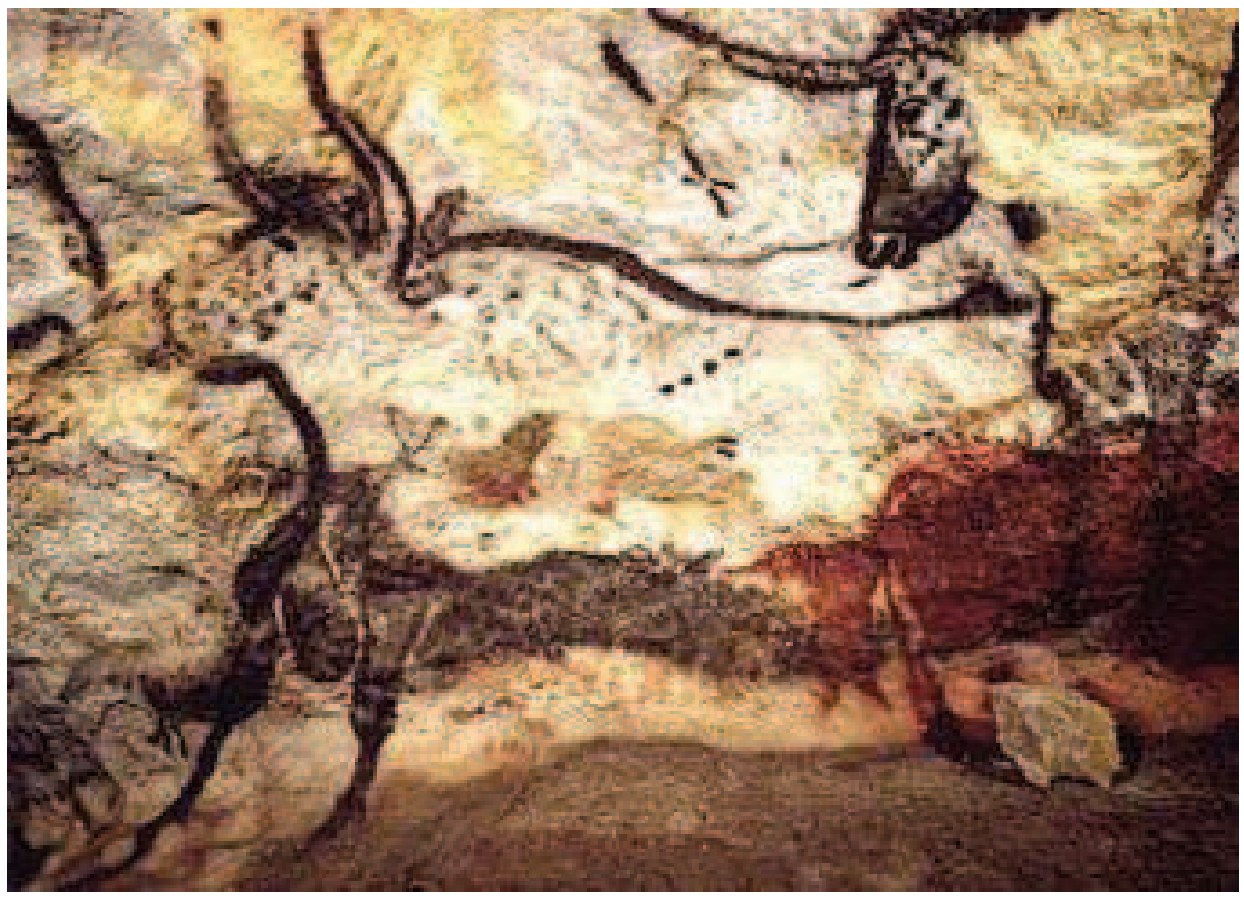

Ryc. 6. Tur z „Sali Byków” w jaskini Lascaux (Breuil, 1952, ryc. 79, s. 112-113)

Fig. 6. Tur from the „Hall of the Bulls” in the Lascaux cave (Breuil, 1952, fig. 79, pp. 112-113) 


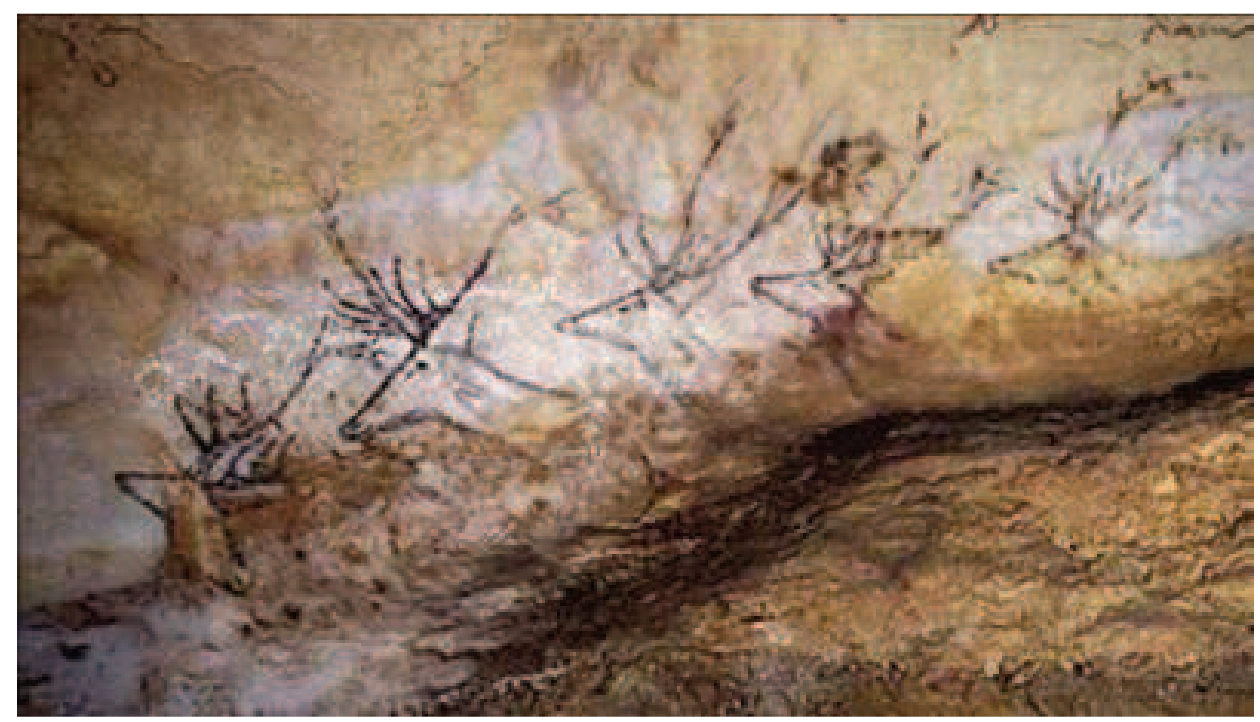

Ryc. 7. Motyw płynących jeleni z jaskini Lascaux (Breuil, 1952, ryc. 93, s. 133).

Fig. 7. Swimming deers from the Lascaux cave (Breuil, 1952, fig. 93, p. 133).

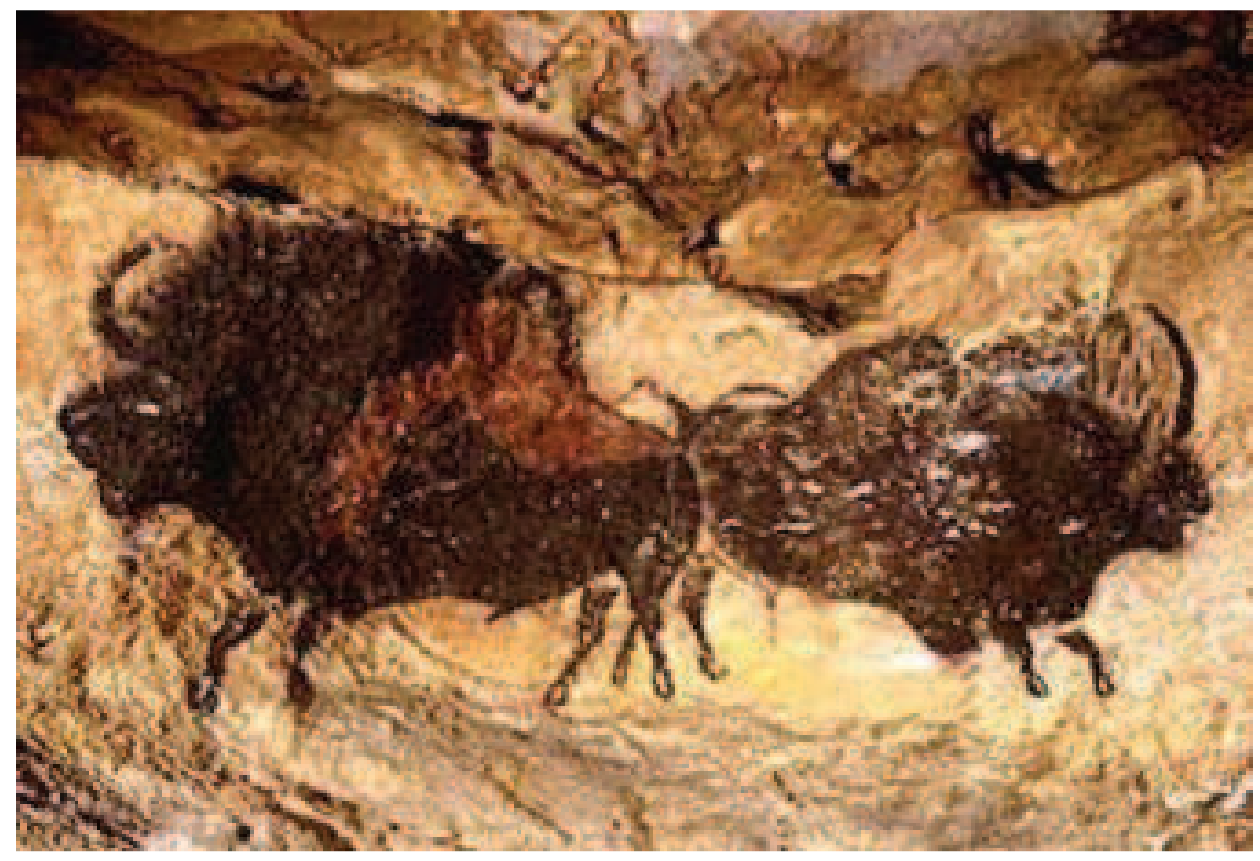

Ryc. 8. Tzw. walczące bizony z jaskini Lascaux (Breuil, 1952, ryc. 91, s. 135)

Fig. 8. The so-called battling bisons from the Lascaux cave (Breuil, 1952, fig. 91, p. 135) 


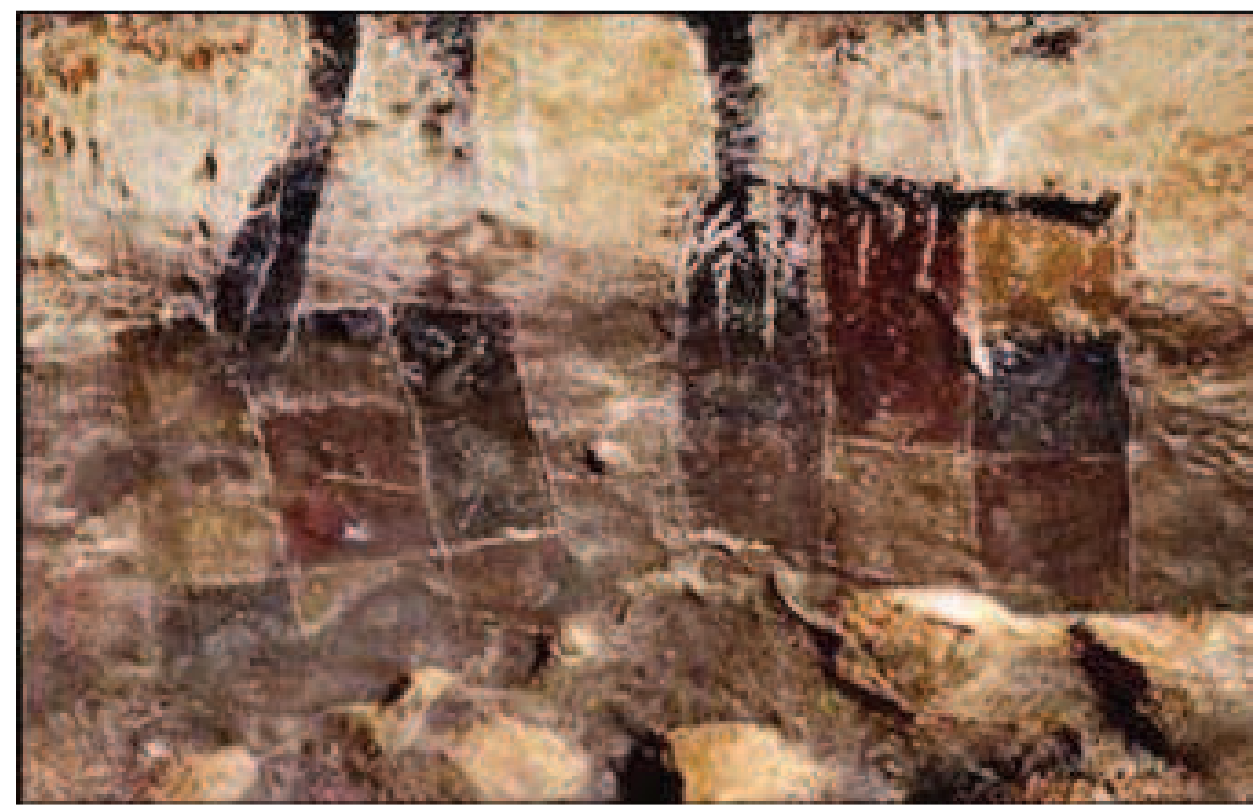

Ryc. 9. Kratki z nogami turów z jaskini Lascaux (Breuil, 1952, ryc. 84, s. 118)

Fig. 9. Geometric paintings with turs legs from the Lascaux cave (Breuil, 1952, fig. 84, p. 118)

Szczegółowe techniki opisano w odniesieniu do wielu i konkretnych jaskiń, np. dla groty Chauvet'a (Chauvet, Deschamps, Hillaire, 1996, s. 110-118).

Najczęściej wykorzystywane były naturalne powierzchnie skał, choć niekiedy skały przygotowywano, skrobiąc je, zyskując w ten sposób jaśniejszą, białą barwę. Rzadziej gruntowano powierzchnię skał (np. na kolor czerwony w Font de Gaume). Umieszczone na tak przygotowanych skałach malowidła wyraźnie się wyróżniały, zwłaszcza na jasnych, zeskrobanych powierzchniach (np. Panel Koni, niektóre partie Panelu Lwów czy mały nosorożec znajdujący się w korytarzu wiodącym do Sali Końcowej w jaskini Chauvet'a). Na powierzchni skał rysowano węglem albo nanoszono farbę lub malowano palcami w warstewce wilgotnej gliny znajdującej się na ścianie jaskini. Wyjątkowo malowano palcami, które najpierw zanurzano w glinie, w farbie (np. grota Baume-Latrone - ryc. 10). Ze zdjęcia Heinricha Wendela (19641970), zamieszczonego w kolekcji profesjonalnych zdjęć zrobionych przez niego w latach 1964-1970, można wnioskować, że nad i pod intencjonalnym malowidłem wykonanym czarną farbą rozprowadzaną palcami występują maźnięcia, w tym jedno bardzo wyraźne, które przybrały niebieski kolor. Jednak ,zniknęły” one na modelu 3D wykonanym w 2013 roku dla tej jaskini; nie były też uwzględniane we wcześniejszych publikacjach naukowych z lat 80. XX wieku. Zdarza się tak, gdy czarną farbę przykryje warstwa kalcytu. Powstaje wówczas wrażenie niebieskiego koloru 
i tak zapewne jest $w$ tym przypadku. Jednak dlaczego nie uwzględniono tego faktu w dokumentacji i wizualizacji tej jaskini i uznano te maźnięcia za nieistniejące? Przykład ten pokazuje trudności już na poziomie samego dokumentowania sztuki jaskiń; badacz decyduje w tym momencie, co nią jest, a co nie.

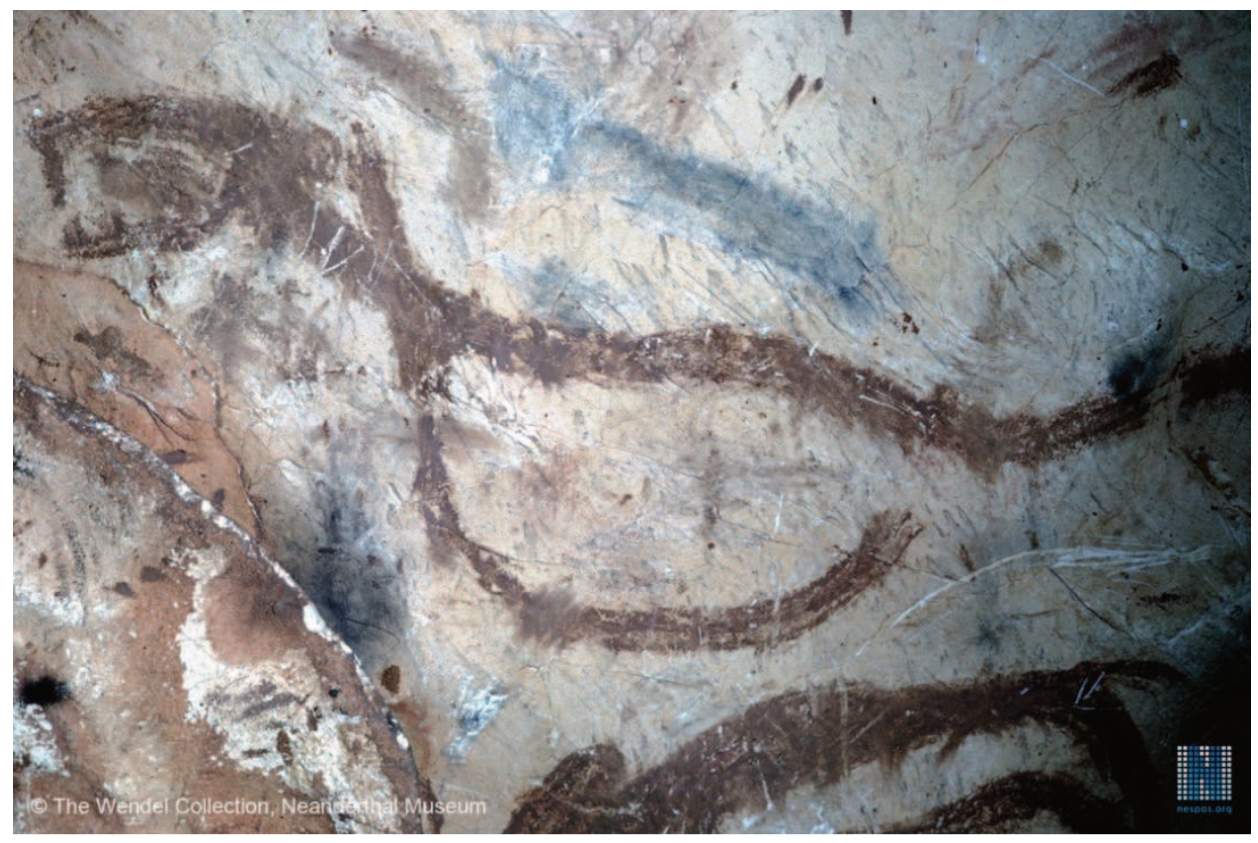

Ryc. 10. Fragment „Wielkiego sufitu” z Baume-Latrone (fot. Heinrich Wendel, The Wendel Collection, Neanderthal Museum)

Fig. 10. A fragment of the „Great Ceiling” of Baume-Latrone (photo Heinrich Wendel, The Wendel Collection, Neanderthal Museum)

Zakres, ilość użytych kolorów zapewne miały znaczenie, ale raczej go nie zgłębimy. Jednym kolorem (choć cieniowanym) pokryto ciało koników z panelu bocznego z jaskini Lascaux (ryc. 11) czy konia z jaskini Le Portel. Konie z Pech-Merle zostały wykonane zasadniczo z czarnych, ale niekiedy przeplatanych czerwonymi kropkami o różnej wielkości (ryc. 12). Zasadniczego, czarnego koloru użyto np. w jaskini Niaux, wprowadzając element czerwonego koloru na „grotach strzał” (ryc. 13). Z kolei w hiszpańskiej Altamirze zastosowano trzy kolory do namalowania bizonów, na dodatek w różnych pozach: śpiących, w ruchu (ryc. 1). Podobnie jest w przypadku przedstawienia w jaskini Chauvet’a dwóch lwów, których kontury oddano czarną farbą, a między nimi namalowano trzeciego lwa, całego w kolorze czerwonym (ryc. 14). Znaczenie kontrastu zapewne niosło treści kulturowe, które dziś trudno rozwikłać. 


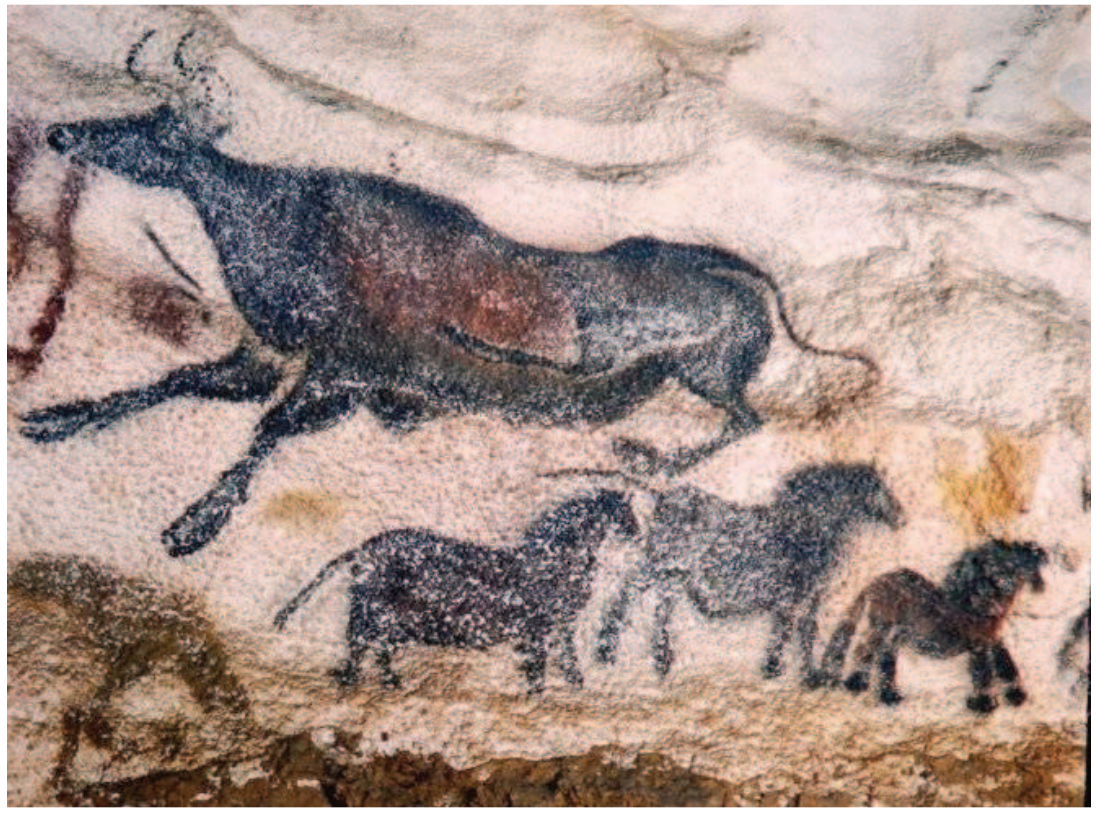

Ryc. 11. Panel boczny z grupą czarnych koni w jaskini Lascaux (Breuil, 1952, s. 126-127).

Fig. 11. Side panel with a group of black horses in the Lascaux cave (Breuil, 1952, pp. 126-127).

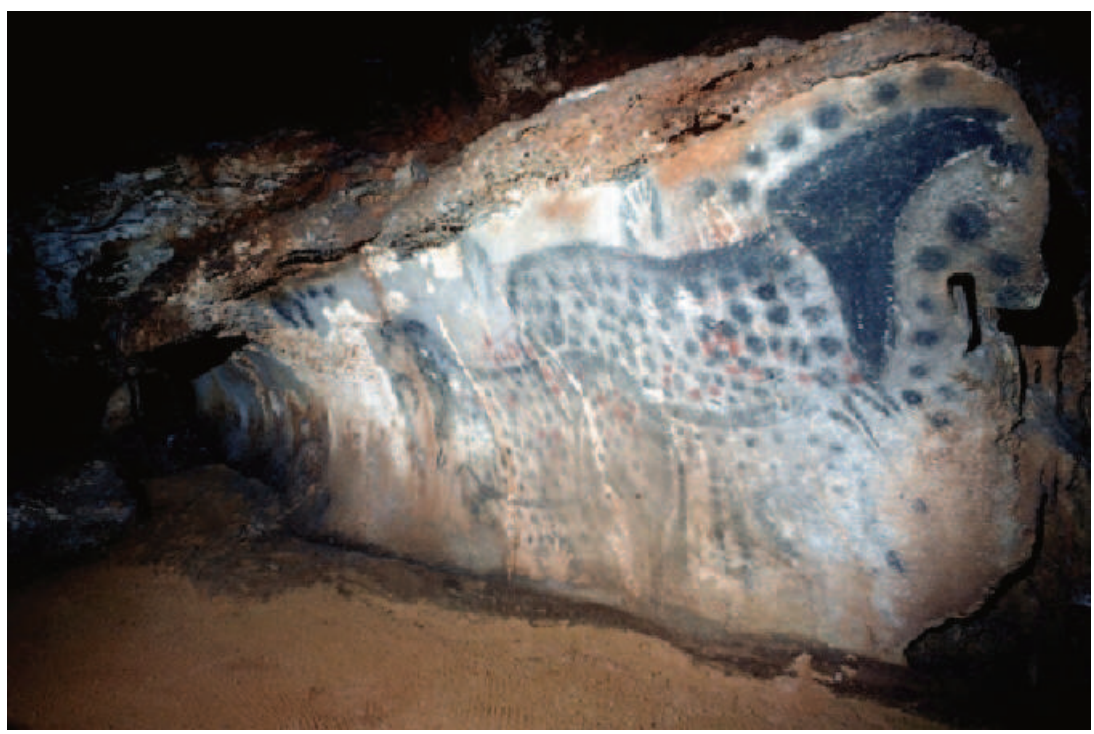

Ryc. 12. Przedstawienia koni z jaskini Le Portel (fot. Heinrich Wendel, The Wendel Collection, Neanderthal Museum)

Fig. 12. Paintings of horses from the Le Portel cave (photo Heinrich Wendel, The Wendel Collection, Neanderthal Museum) 


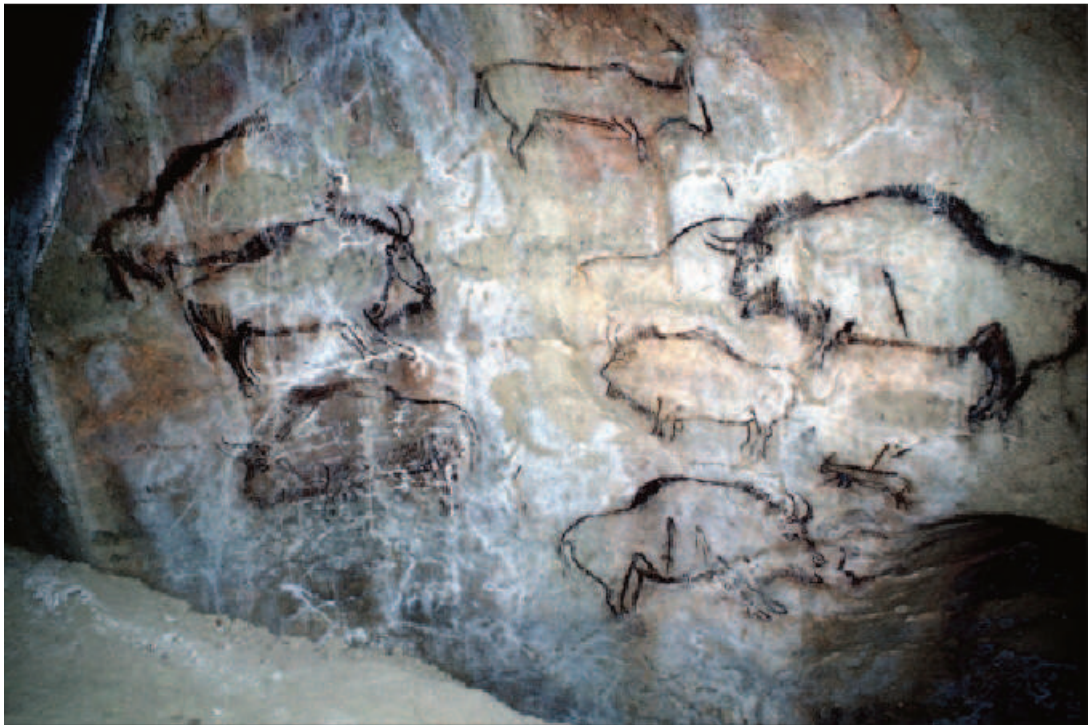

Ryc. 13. Panel z Salon Noire w jaskini Niaux (fot. Heinrich Wendel, The Wendel Collection, Neanderthal Museum)

Fig. 13. Panel from Salon Noire in the Niaux cave (photo Heinrich Wendel, The Wendel Collection, Neanderthal Museum)

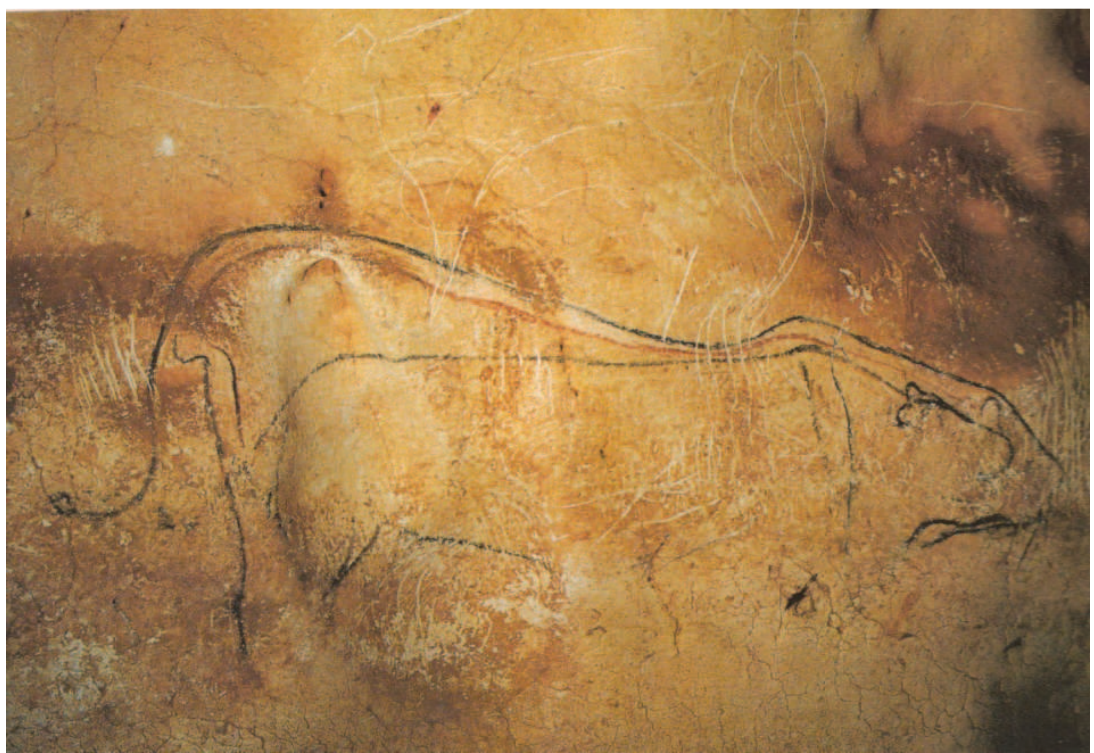

Ryc. 14. Przedstawienie trzech lwów z jaskini Chauvet'a: w środku, między dwoma rysunkami w czarnym kolorze, lew wykonany czerwoną farbą (Chauvet, Deschamps, Hillaire, 1996, ryc. 93, s. 122)

Fig. 14. Paintings of three lions from the Chauvet cave: in the middle, between two drawings in black color, a lion made with red paint (Chauvet, Deschamps, Hillaire, 1996, fig. 93, p. 122) 


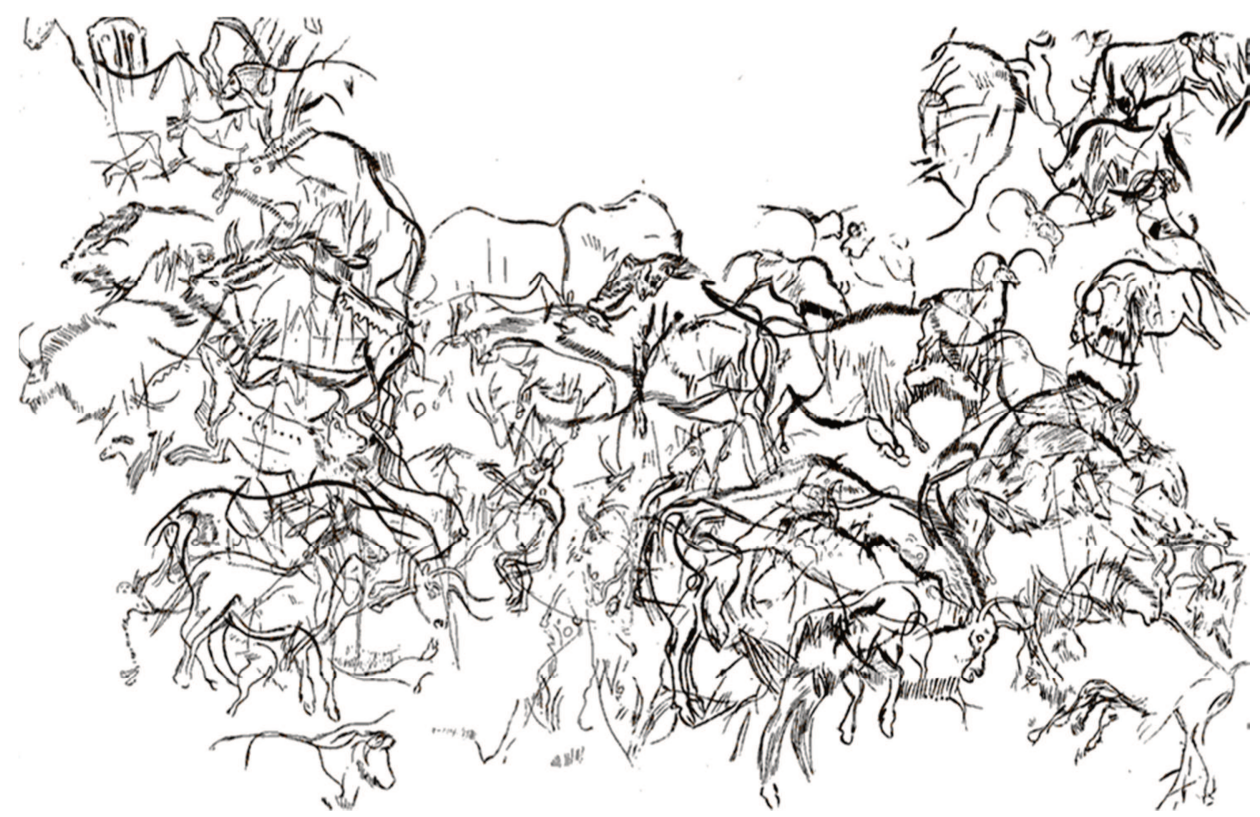

Ryc. 15. Ryty naskalne z groty Trois Frères (Breuil, 1952, ryc. 129, s. 164-165)

Fig. 15. Rock carvings from the Trois Frères cave (Breuil, 1952, fig. 129, pp. 164-165)

Kolejny rodzaj pytań to rozważania na temat rysunku i formy oraz jego stosunku do koloru. Rozważany jest problem, czy kolor stanowi istotny, czy nieistotny dodatek do formy oraz czy adekwatne obrazowanie można było uzyskać, stosując samą linię (Gage, 2008, s. 117). W jaskiniach paleolitycznych stosowano samą linię rytą, a widoczne jest to w rytach naskalnych. Najbardziej ,podręcznikowym” przykładem jest jaskinia Trois Frères (ryc. 15), gdzie dominują ryty w postaci doskonałych form zwierząt, choć zachodzące na siebie w swoistej plątaninie i swoistym palimpseście. $\mathrm{W}$ takim przypadku kolor nie jest konieczny. Kolor w przypadku malowideł na ścianach jaskiń stanowi wzmocnienie formy, nadaje jej głębi, powoduje zjawisko iluzji.

\section{Iluzja}

Powyższe rozważania dotyczyły znaczenia i treści kulturowych kolorów „obrazów" pradziejowych. Uważam, że należy dodać do nich ważny aspekt - złudzenie. W sukurs przychodzą poglądy H. Gombricha (1981), które dotyczą tego ważnego aspektu sztuki, jakim jest złudzenie. Pomysł ten został zastosowany przez autora przy wyjaśnianiu rozwoju nowego stylu, jakim był styl klasyczny w sztuce greckiej, a które to idee wyłożył w monografii z 1981 roku pt. Sztuka i złudzenie. O psychologii przedstawienia zmysłowego. Uznał, że ten przełom, radykalna zmiana polegały 
na wprowadzeniu przez Greków złudzenia, iluzji oraz na zastosowaniu narracji. Odnosiło się to zarówno do obrazów, jak i przedstawień na scenie. Zdaniem Gombricha była to jedna $\mathrm{z}$ ważniejszych radykalnych zmian $\mathrm{w}$ dziejach obrazowania $\mathrm{w}$ naszej kulturze, do dziś w niej obecna. Według niego w dziele sztuki obowiązują pewne schematy obrazowe jako zapis postrzegania świata, tworzone i stale modyfikowane. Dotyczy to nie tylko artystów, ale też - co bardzo ważne - odbiorców tych dzieł, którzy mają określone oczekiwania i myślowe wyobrażenia o obrazach, wpływające na odbiór dzieł. Ta nowatorska perspektywa Gombricha uwzględnia konwencję stylistyczną, ale w połączeniu z ekspresją i aktywnym przeżywaniem odbioru dzieła.

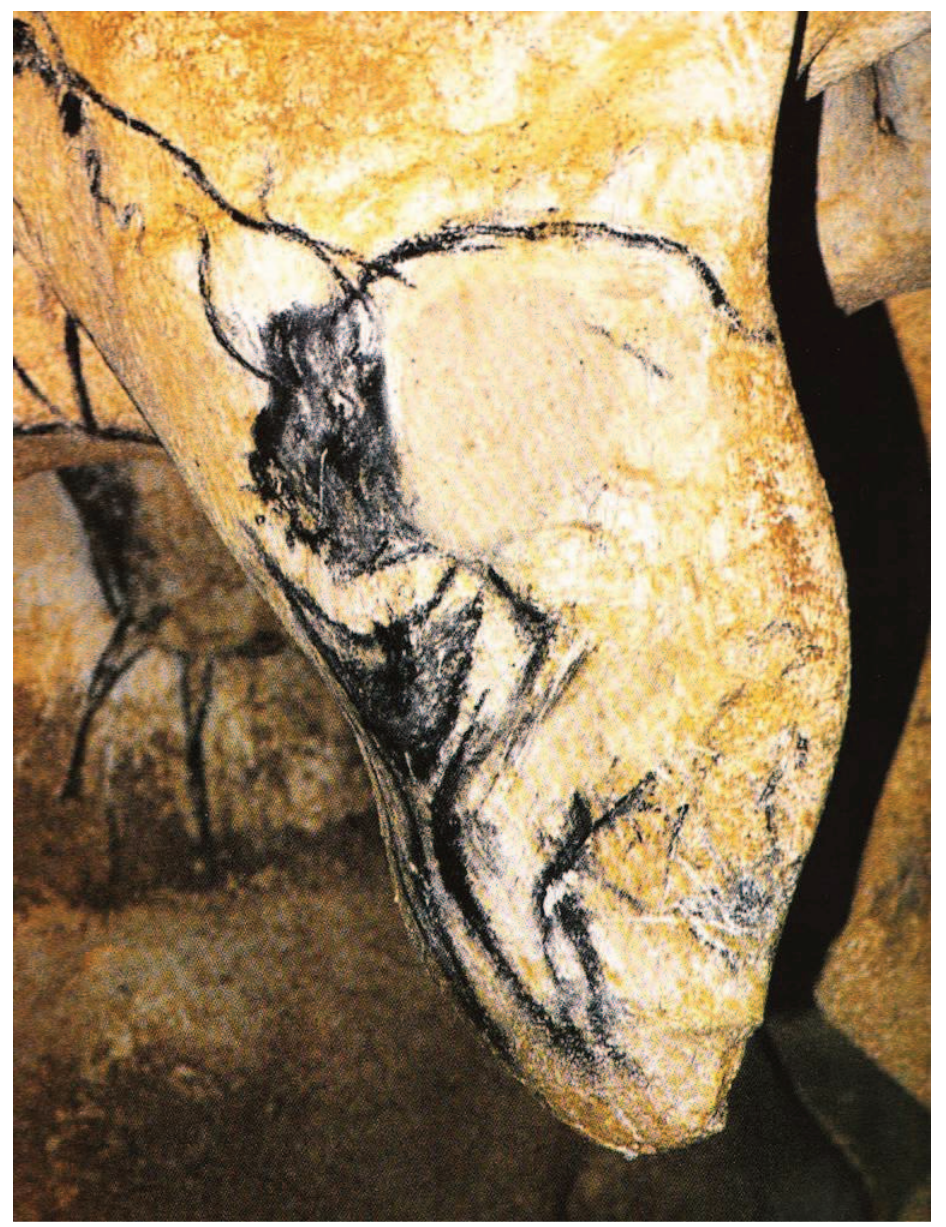

Ryc. 16. Postać antropomorficzna (bizono-człowiek) z jaskini Chauvet'a (Chauvet, Deschamps, Hillaire, 1996, ryc. 93, s. 122)

Fig. 16. Anthropomorphic figure (bison-man) from the Chauvet cave (Chauvet, Deschamps, Hillaire, 1996, fig. 93, p. 122) 


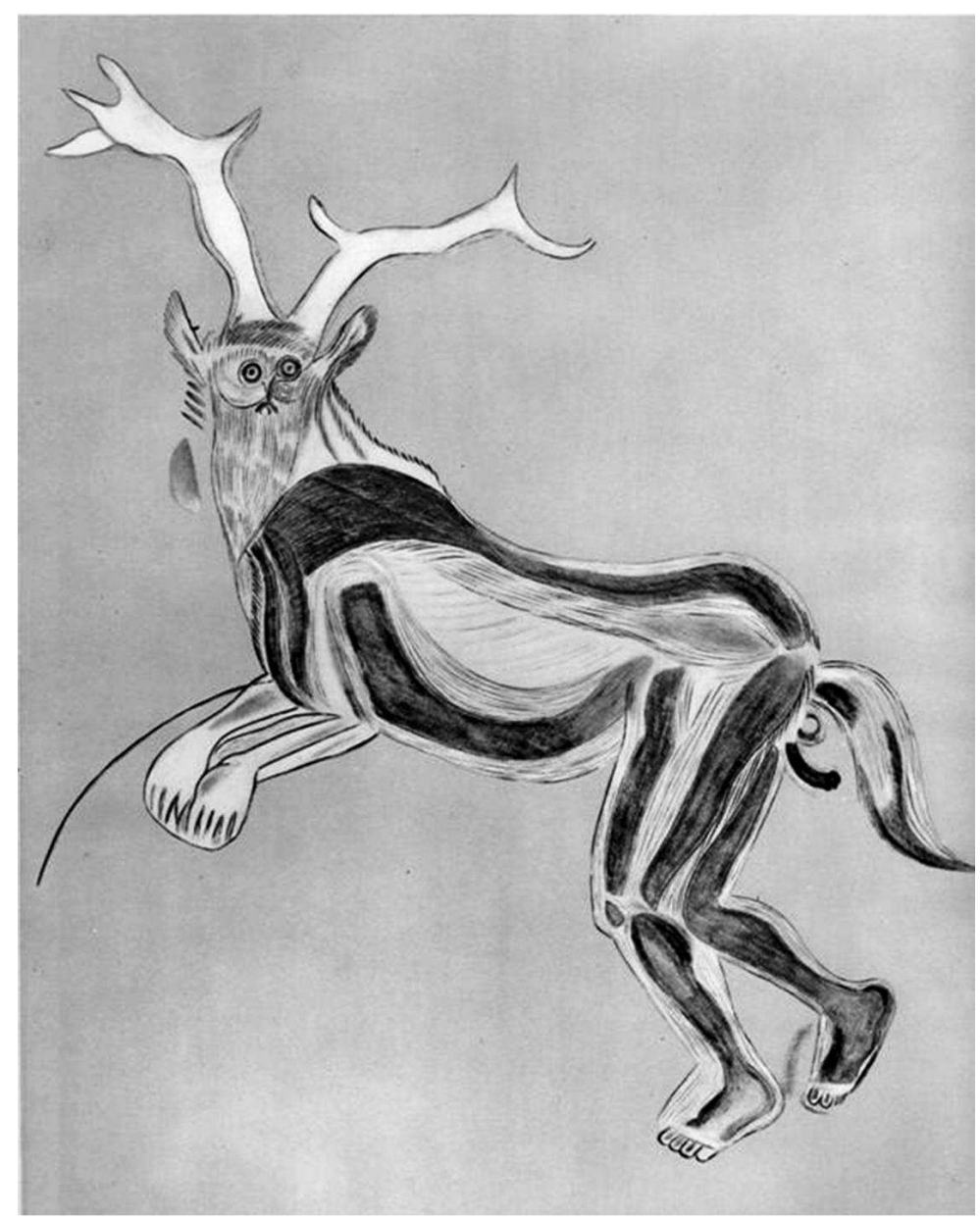

Ryc. 17. Tzw. czarownik z jaskini Trois Freres (Breuil, 1952, ryc. 130, s. 167)

Fig. 17. The so-called sorcerer from the Trois Freres cave Freres (Breuil, 1952, fig. 130, p. 167)

Gombrich przypisuje „odkrycie” zjawiska złudzenia starożytności, jednak jak się wydaje - istniało ono wcześniej, w pradziejach. W paleolitycznych jaskiniach kolor, kontrast, cień pełniły niezwykle istotną rolę - czyniły z niej oswojony „ludzki” świat. Dodatkowo to one tworzyły iluzję głębi przedstawienia, plastyczności czy danego zwierzęcia, nawet jeśli długo go nie widziano w okolicy, np. w Lascaux przedstawienie bizonów (ryc. 8). Widz doznawał złudzenia realności „obrazu”, a to działało na odbiór społeczny. Ewidentna iluzja to według mnie występowanie figur dwuznacznych - ni to człowiek, ni to zwierzę - antropomorficznych, wzmocnionych kontrastem między czarną farbą a jasnym podłożem skalnym, np. kobieta-bizon w jaskini Chauvet'a (ryc. 16). Nieco w innym sposób został wykonany jeden z tzw. 
czarowników z Trois Frères, z bocznego korytarza (ryc. 17). Iluzję stworzono za pomocą kontrastu między kolorem czarnym a żółtym. Taki efekt daje zarys części anatomicznych tej postaci w tych dwóch kolorach. Czy elementem iluzji były przedstawienia rąk ludzkich, np. w jaskini El Castillo (ryc. 18)? A także schematyczne przedstawienia $\mathrm{w}$ intensywnie czerwonym kolorze $\mathrm{z}$ tej samej groty El Castillo (ryc. 19). Ale iluzję realności zwierzęcia daje również płynne przejście i ciepłe kolory od czerwonego do ciepłego tonu brązu, np. tur z Lascaux (ryc. 20).

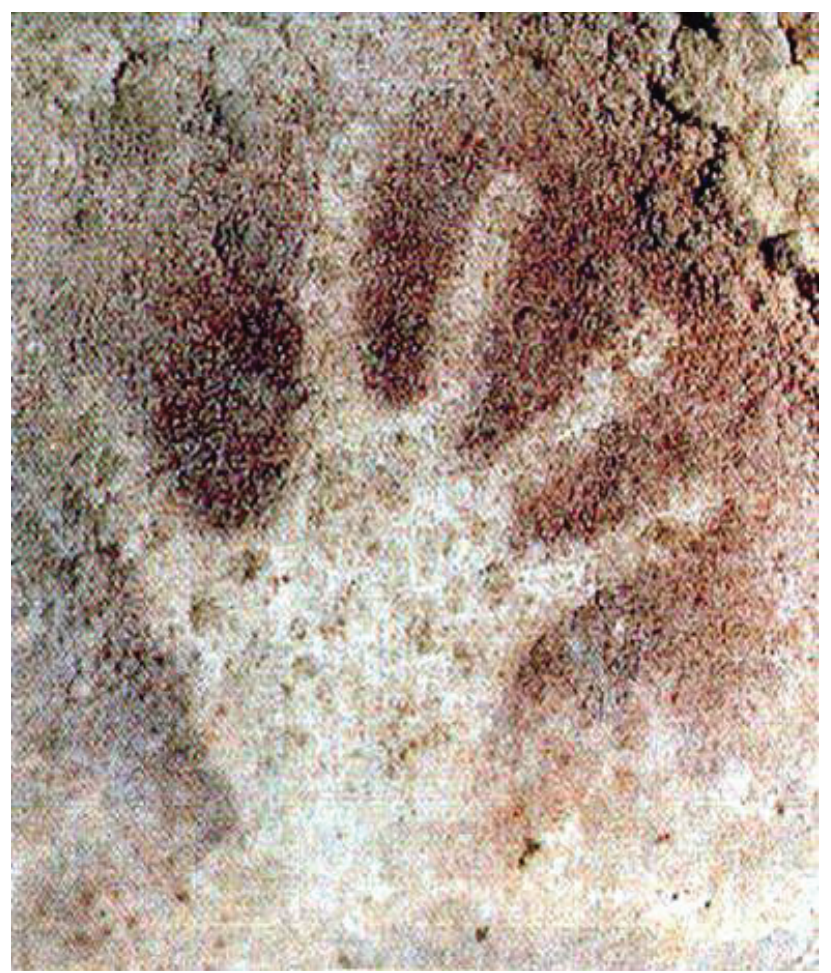

Ryc. 18. Obrys ręki czerwoną wydmuchiwaną farbą z jaskini El Castillo (Breuil, 1952, ryc. 456, s. 364) Fig. 18. The outline of the hand with red blown paint from the El Castillo cave (Breuil, 1952, fig. 456, p. 364)

Ta zaobserwowana powtarzalność relacji dotyczy koloru, ruchu i iluzji. Składają się one na efekt „działania” obrazu. W aspekcie koloru występuje moim zdaniem powtórzenie relacji np. między czerwonym a czarnym, następnie czarnym a czerwonym i żółtym, w stosunku do struktury ścian, oświetlenia tychże ścian i ich naturalnych barw, choć mamy świadomość, że te same barwy mogły już wówczas mieć różne znaczenie w zależności od kontekstu. Co więcej, ta sama barwa, w zależności od struktury ściany, kąta jej oświetlania, światła mogła być odbierana jako inna. 


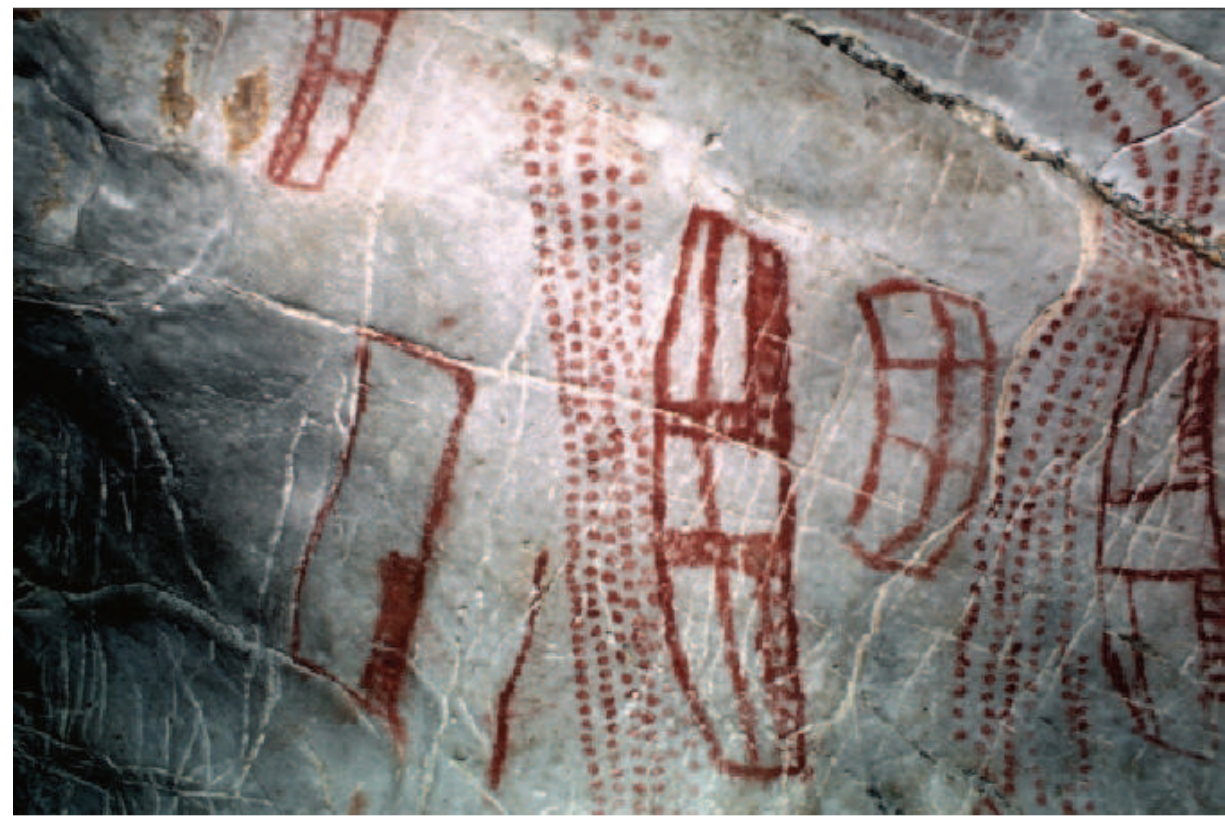

Ryc. 19. Figury geometryczne z jaskini El Castillo (Breuil, 1952, ryc. 457, s. 366)

Fig. 19. Geometric figures from the El Castillo cave (Breuil, 1952, fig. 457, p. 366)

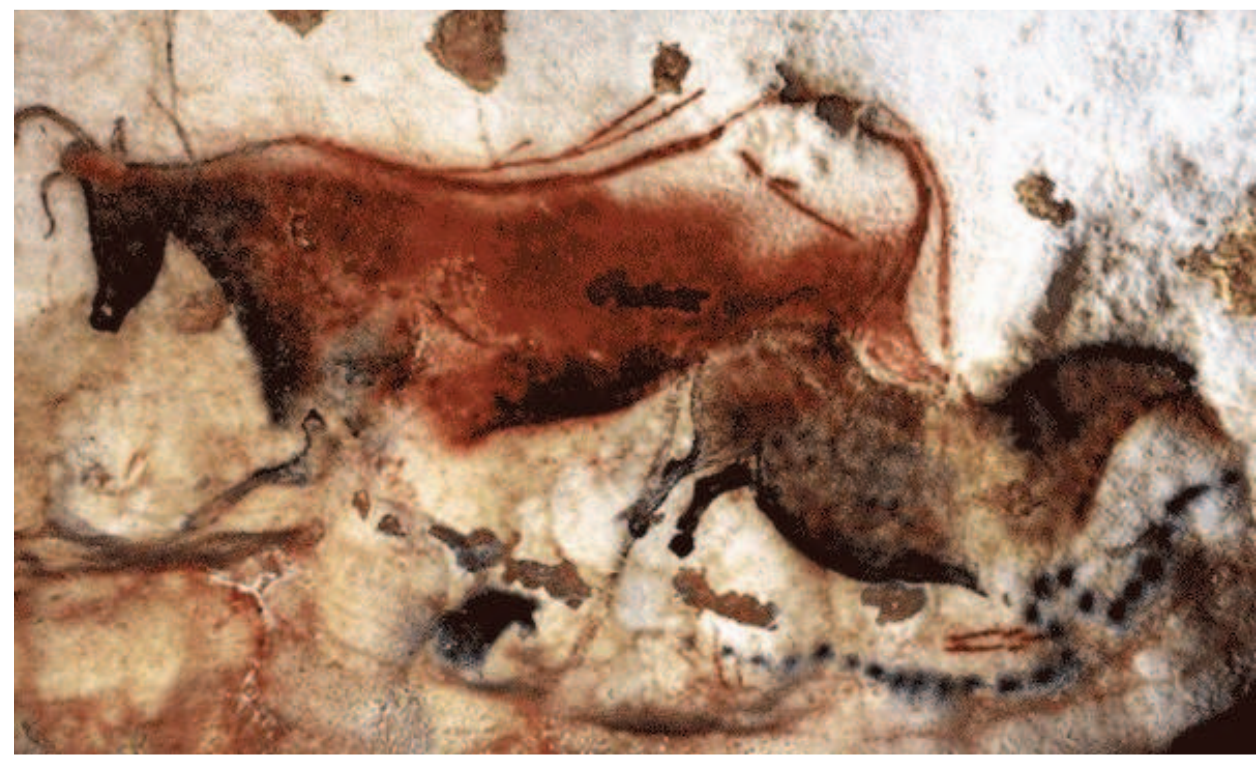

Ryc. 20. Tur z jaskini Lascaux (Breuil, 1952, ryc. 74, s. 108)

Fig. 20. Tur from the Lascaux cave (Breuil, 1952, fig. 74, p. 108) 
Bardzo istotny i modny rodzaj pytań również ostatnio $\mathrm{w}$ archeologii to problem zespolenia harmonii koloru z dźwiękiem. Już niektórzy starożytni Grecy uważali, że kolor jest obok wysokości i czasu trwania cechą dźwięku jako takiego, a ludzie muzykalni często kojarzą dźwięk z kolorem. Mówimy w tym miejscu o specyficznym rozumieniu i percepcji koloru. Obecnie nietrudno nawet matematycznie opisać podobieństwa między zapisem dźwięku i koloru. Dostrzegamy, że muzyka i malarstwo mają ze sobą wiele wspólnego. W obydwu chodzi o harmonię, są trudne do uchwycenia i sprecyzowania, opierają się na wrażeniach, nastrojach. Posiadają również swoje teorie, swój sposób zapisu, które opierają się na bardzo podobnych i zbliżonych schematach. W obu tych zjawiskach mamy skale i subtelne przejścia o tony i barwy, sekwencje kolorów. Jednak są to poglądy XX-wieczne. I tak Morgan Russel - malarz, synchronista - stosował terminologię tonacji, dominanty i kontrapunktu, aby opisać swoje zasady konstrukcji koloru. Muzyka koloru to sztuka, której zawsze niewiele brakowało do tego, aby stać się najważniejszą sztuką XX wieku. Swoistego rodzaju proroctwo wypowiedział Cyril Scott w swojej książce Music and its Secret Influence throughout the Ages, pisał, że: „nadejdzie czas, kiedy [...] w półmroku na ekran będą rzutowane kolory wszelkich rodzajów, które będą wyrażać treść muzyczną i korespondować z nią. Będzie to realizacja marzenia Skriabina o jedności barwy i dźwięku, a przez tę realizację publiczność przyszłości doświadczy uzdrawiającego działania tego potężnego zespolenia" (Scott, 1996, za: Gage, 2008, s. 246). A może tego głębokiego zespolenia doznawała już ludzkość w głębokich mrokach przeszłości? Czy możemy się spodziewać takiego zespolenia? Jak się wydaje $\mathrm{w}$ takim duchu czynione są doświadczenia $\mathrm{w}$ malowanych jaskiniach, potwierdzające harmonię formy, koloru i dźwięku, np. we francuskiej jaskini Niaux, której forma wewnętrzna z wysokim sklepieniem przypomina dzisiejsze sale koncertowe i posiada walory takiej sali, ponieważ głos śpiewaków rozchodzi się w niej harmonijnie. Istniejące $\mathrm{w}$ niej echo wraca niekiedy siedmio- lub ośmiokrotnie. Prawdopodobnie wspomniane wyżej „marzenie Skriabina” zrodziło się już w głębokich pradziejach, w paleolicie, w korelacji malowideł w miejscach o najlepszej akustyce.

\section{WYBÓR KOLORÓW JAKO ELEMENT INTERTEKSTUALNOŚCI}

Operowanie tylko, a może aż trzema podstawowymi kolorami przez ludzi paleolitu (w dwunastu odcieniach) może świadczyć o tym, że skupiali się oni na trwałości barw jako materialnej substancji, a niekoniecznie na dbałości o formę. Jednak dla badaczy kolorów, od lingwistyki po psychologię, zastanawiające jest to, że mimo ogromnej wielości niuansów kolorów w danej społeczności wybierano kilka barw podstawowych i tych się trzymano, co świadczy, że kolor jest silnym bodźcem wizualnym. 
Idąc tropem tezy, że doświadczenie koloru jest różne dla różnych grup w kulturze i zależy w głównej mierze od kategorii zajęć, którymi się zajmowali ludzie paleolitu, a które kształtowały sposób ich myślenia, a to z kolei wpływało na ich funkcjonowanie, także „praktyczne”. Wśród nich niewątpliwie istotna była grupa myśliwych. Były więc dla nich ważne bizony, na które polowali, tury, konie czy inne zwierzęta żyjące $w$ ich ekumenie. Ale czy tylko były one ważne jako źródło pożywienia? Nie należy tak sądzić. Niuanse kolorów, w jakich wykonano te zwierzęta, potwierdzają tą tezę. Odnieśmy to do przedstawień koni. Określona technika ich wykonania wskazywała na różnice w umaszczeniu koni, a nie tylko na odmienną manierę wykonawcy, np. w Pech-Merle (ryc. 12) konie zostały wykonane za pomocą czarnych kropek, a głowy pomalowane w całości czarną farbą. Czy mógłby to być mały konik, ale siwy dropiaty? Zakłada się, że w jaskiniach przedstawiano małe konie przypominające późniejsze koniki Przewalskiego, dość mocno zbudowane o umaszczeniu beżowym do brązowego. W samej Lascaux występują konie w kolorach od żółtego (tzw. chiński koń) do beżowo-brązowych i czarnych. Te różne barwy są tłumaczone jako oddające zmienność sezonową umaszczenia konia (jaśniejsze w zimniejszej porze, też o dłuższej sierści zimą), ale chyba nie tylko taki był ich sens. W samej Lascaux są przedstawienia koni dość mocno zbudowanych, choć niektóre są delikatniejsze, o smuklejszych szyjach, głowach, a wszystkie o umaszczeniu od jasno- do ciemnobrązowego, a sam spód ciała zwierzęcia żółtawobiały, grzywa i ogon - czarne, kończyny od stawów nadgarstkowych i skokowych również czarne. Wzdłuż grzbietu często biegnie ciemna pręga (ryc. 5). Jednak niektóre ciała koni mają plamki (łatki), ciemne pręgi na bokach itp., co oznacza, że zapewne zdarzały się takie odstępstwa w umaszczeniu i były to cechy istotne dla tamtych ludzi. Dłuższa sierść zimą układała się w taki sposób, że również tworzyła złudzenie plam. Idąc dalej, można przypuszczać, że ludzie ci musieli wytworzyć adekwatne określenia językowe, uwzględniając niuanse kolorystyczne. Stosowali kolory czarny, żółty, czerwony oraz ich odcienie zapewne nieprzypadkowo, zarówno w celach praktycznych, jak i symbolicznych. Nie zmienia to faktu, że kolor miał i ma praktyczne znaczenie $\mathrm{w}$ wielu dziedzinach życia, również w rozwoju słownictwa i mowy, a więc kognitywne. Wybór koloru nie jest przypadkowy. Dzisiejsze prace psychologiczne wskazują, że kolor oddziałuje na świadomość i podświadomość ludzi i w istocie kształtuje ich działania. Kolory pobudzają wyobraźnię grupową i łączą ludzi. Dlatego budzą w odbiorcy określone emocje i odsyłają do konkretnych miejsc, wydarzeń, przedmiotów, do owej pamięci percepcyjnej.

Z powyższych rozważań wynika, że w kwestii funkcji kolorów istnieją w kulturze przynajmniej dwa podejścia; jedno starające się poszukiwać uniwersalnych zasad, a drugie indywidualizujące rolę i znaczenie kolorów dla poszczególnych społeczności. Krzysztof Jurek (2011, s. 80) przypisuje kolorom pewne „uniwersalne" funkcje, takie jak: 
a) wyznaczanie przestrzeni społecznej i tworzenie w niej konkretnych miejsc, np. wydzielonych jako sacrum; kolory podkreślają istotę, wagę takich miejsc;

b) funkcja percepcyjna - inaczej odbieramy kontrast kolorów na zasadzie czerwony-czarny, kolor umożliwia percepcję rzeczywistości w kategoriach danej kultury;

c) funkcja znaczeniowa - kolor może mieć określone znaczenie, również symboliczne w kontekście danej kultury;

d) funkcja integrująca - grupy czy kultury używające dane kolory wykształcają i utrwalają podobną tożsamość, przywołują podobne wartości, zachowania;

e) funkcja komunikacji pozawerbalnej - kolory mogą stanowić dobre rozróżnienie na „my” i ,oni”, swój - obcy;

f) funkcja utrwalania stereotypów oparta na perswazji - pozytywne lub negatywne skojarzenia $\mathrm{z}$ danym kolorem pobudzają do działania i utrwalają je, co powoduje, że w określonych sytuacjach, np. obrzędów, zwyczajów zachowamy się tak, jak one nakazują;

g) funkcja estetyczna lub emotywna - kolory wykorzystywane są zarówno w sztuce, jak i w życiu codziennym dla wrażeń, emocji doznań.

Moim zdaniem znaczenie koloru/ów polega w istocie na pełnieniu funkcji określanej przez P. Ricoeur'a (2000) jako „,mediatyzacja”, zasadza się to na mediowaniu między teraźniejszością a przeszłością. Dotyczy ono ważnych treści z przeszłości, istotnych wręcz dla egzystencji danej wspólnoty. Poprzez owe obrazy negocjowano treści i wydarzenia, które należało pamiętać, do nich się odwoływać i ich strzec, a które uznawano za nieważne i odchodziły w niepamięć. Ta misja mogła być spełniana przez „obrazy” w jaskiniach. Ale by to było możliwe, to musiały one pozostawać w związkach intertekstualnych i w takim sensie ówczesny świat miał pewne cechy uniwersalne. Może o tym świadczyć ilość ozdobionych jaskiń, liczona w setkach. Także uderzające podobieństwo motywów, zasadniczo zwierzęcych. Fakt, że prawie nie przedstawiano w nich ludzi, miał zapewne ważne konotacje kulturowe - świadczy wymownie o związkach międzyobrazowych. To, że istnieje pewna konwencja przedstawiania zwierząt w ruchu czy we śnie - również świadczy o związkach obrazów; podobnie brak zaznaczania płci zwierzęcia, a zamiast tego umieszczanie znaków przy nich. Również użycie jednego, dwóch lub wyjątkowo trzech kolorów potwierdza powyższą tezę. Wydaje się, że kolor traktowano jako materialną substancję, a jednocześnie jako bodziec wizualny i w taki sposób zapewniał on trwałość związków między obrazami na ścianach jaskiń.

Jak pisze Krzysztof Jurek (2011, s. 80): „Pomimo postępu oraz rozwoju różnych dziedzin nauki, licznych badań opartych na wiedzy z zakresu optyki, fizyki, fizjologii, w celu ustalenia jakichś ogólniejszych praw harmonii barw dla potrzeb technologii przemysłu, rzemiosła, sygnalizacji, drukarstwa, szkolnictwa i wielu innych dziedzin życia, kolory nadal są źródłem dyskusji i wielu znaków zapytania”. Ta 
sytuacja dotyczy także dociekań archeologicznych, co nie zmienia faktu, że kolory są ważnym tematem, a niniejsze rozważania to jedynie wstęp do dalszych studiów nad kolorem i jego rolą w kształtowaniu związków między „obrazami” w paleolitycznych grotach.

\section{BIBLIOGRAFIA}

Antoniewicz W.

1957 Historia sztuki najdawniejszych społeczeństw pierwotnych. Warszawa: Wydawnictwo Naukowe PWN.

Arystoteles

1990 O barwach. W: Dzieła wszystkie (T. 4). Warszawa: Wydawnictwo Naukowe PWN.

Bahn P. i Renfrew C.

2002 Archeologia. Teorie, metody, praktyka. Warszawa: Prószyński i S-ka.

Barthes R.

1999a Śmierć Autora. Teksty Drugie: teoria literatury, krytyka, interpretacja, 1/2(54/55), s. $247-251$

Barthes R.

1999b S/Z. Warszawa: Wydawnictwo KR.

Belting H. G.

2001 Bild-Anthropologie. Entwürfe für eine Bildwissenschaft. München.

Beltrán A.

1998 Introduction. W: P. A. Saura Ramos (red.), Altamira (s. 9-16). Barcelona - Madrid: Lunwerg Editores.

Bociek B. (red.)

2009 Kolor i kultura. Teoria i znaczenie koloru od antyku do abstrakcji, John Gage. Studia Elblaskie, 10, s. 437-443.

Boehm G.

$2014 O$ obrazach $i$ widzeniu. Antologia tekstów. Kraków: UNIVERSITAS Towarzystwo Autorów i Wydawców Prac.

Buczyńska-Garewicz H.

1994 Semiotyka Peirce'a. Warszawa: Zakład Semiotyki Logicznej Uniwersytetu Warszawskiego. Znak - Język - Rzeczywistość, Polskie Towarzystwo Semiotyczne.

Breuil H.

1952 Four hundred centuries of cave art. Paris: Montignac, Centre d'Etude et de Documentation Préhistoriques.

Bugaj E.

2012 Archeologia a sztuka. W: S. Tabaczyński, A. Marciniak, D. Cyngot, A. Zalewska (red.), Przeszłość społeczna. Próba konceptualizacji (s. 885-909). Poznań: Wydawnictwo Fundacji UAM.

Chauvet J.-M., Deschamps E. B., Hillaire Ch.

1996 Dawn of Art: The Chauvet Cave. The Oldest Known Paintings in the World. London: Thames and Hudson. 
Chippendale C. i Taçon P. S. C.

1998 An archaeology of rock-art. Through informed methods and formal methods. W: C. Chippindale i P. S. C. Taçon (red.), The archaeology of rock Art. Cambridge: University Press.

Czekalski S.

2006 Intertekstualność $i$ malarstwo. Problemy badań nad zwiazkami międzyobrazowymi. Poznań: Wydawnictwo Naukowe UAM.

Filip J.

1974 Anfänge der Kunst in Europa. W: Propyläen Kunstgeschichte, T. 13: Frühe Stufen der Kunst (s. 73-121). Berlin: Propylen Verlag Berlin.

Garcia Guinea M. A.

$2001 \quad$ Altamira and other Cantabrian caves. Madrid: Silex Ediciones.

Gage J.

2008 Kolor i kultura. Teoria i znaczenie koloru od antyku do abstrakcji. Kraków: Wydawnictwo Prac Naukowych Universitas.

Gage J.

2013 Kolor i znaczenie. Kraków: Wydawnictwo Prac Naukowych Universitas.

Gąssowski J.

1996 Prahistoria sztuki. Warszawa: Trio.

Gediga B.

2010 Przejawy antropomorfizacji w sztuce pradziejowej. W: E. Bugaj, A. P. Kowalski (red.), Estetyka $w$ archeologii. Antropomorfizacje w pradziejach (s. 47-82). Poznań: Wydawnictwo Poznańskie.

Gediga B., Łaciak D., Łydżba-Kopczyńska B., Markiewicz M.

2017 Świat kolorów garncarzy z rejonu Domasławia sprzed około 2800 lat. Wrocław: IAiE PAN.

Gediga B., Mierzwiński A., Piotrowski W. (red.)

2001 Sztuka epoki brąu i wczesnej epoki żelaza w Europie Środkowej. Wrocław - Biskupin: Muzeum Archeologiczne w Biskupinie, Komisja Archeologiczna Wrocławskiego Oddziału PAN.

Gediga, B., Piotrowski, W. (red.)

2008 Sztuka pradziejowa i wczesnośredniowieczna jako źródto historyczne. Biskupin - Wrocław: PAN oddział we Wrocławiu, Muzeum Archeologiczne w Biskupinie.

Gombrich E. H.

1981 Sztuka i ztudzenie. O psychologii przedstawienia zmysłowego. Warszawa: Państwowy Instytut Wydawniczy.

Gombrich E. H.

2016 O sztuce. Poznań: Rebis.

Gray R. D.

1952 Goethe the Alchemist: A Study of Alchemical Symbolism in Goethe's Literary and Scientific Works. Cambridge: Cambridge Library Collection - Literary Studies.

Hoernes, M.

1925 Urgeschichte der bildenden Kunst in Europa von den Anfängen bis um 500 vor Christi (wyd. 3). Wien: A. Schroll. 
Jurek K.

2011 Znaczenie symboliczne i funkcje koloru w kulturze. Kultura - Media - Teologia, 6, s. $68-80$.

Kębłowski S.

1987 Dzieje sztuki polskiej. Warszawa: Arkady.

Lamiable J.-N.

2005 La grotte de Niaux au cours des temps modernes. Etude preliminaire des graffiti de la grotte de Niaux et de leurs auteurs. Préhistoire Art et Sociétés, 61, s. 11-34.

Layton R.

1981 The Anthropology of Art. London: Granada Publishing.

Leroi-Gourhan A.

1965 Religie przedhistoryczne. Warszawa: Wydawnictwo Naukowe PWN.

Mierzwiński A.

2001 Sztuka pradziejowa jako sztuka w pradziejach. W: B. Gediga, A. Mierzwiński i W. Piotrowski (red.), Sztuka epoki brąu i wczesnej epoki żelaza w Europie Środkowej (s. 93-108). Wrocław - Biskupin: Muzeum Archeologiczne w Biskupinie, Komisja Archeologiczna Wrocławskiego Oddziału PAN.

Minta-Tworzowska D.

2011 Badania nad kulturą wizualną i ich wpływ na konstruowanie obrazów przeszłości przez archeologów. W: R. Zapłata (red.), Digitalizacja dziedzictwa kulturowego. Wybrane zagadnienia (s. 215-334). Lublin: Instytut Archeologii WNHiS UKSW.

Peirce Ch.

1997 Wybór pism semiotycznych. Warszawa: Znak - Język - Rzeczywistość, Polskie Towarzystwo Semiotyczne.

Peirce Ch.

1965 Jak uczynić nasze myśli jasnymi. W: Peirce, tłum. H. Buczyńska-Garewicz, Seria Myśli i Ludzie. Warszawa: Wiedza Powszechna.

Ricoeur P.

2000 L'écriture de l'histoire et la représentation du passé. Annales HSS, 4, s. 731-747.

Rozwadowski A.

2002 Spiritus and Stones. Shamanism and Rock Art in Central Asia and Siberia. Poznań: Wydawnictwo Naukowe UAM.

Rozwadowski A.

2003 Indoirańczycy - sztuka i mitologia. Petroglify Azji Środkowej. Poznań: Wydawnictwo Naukowe UAM.

Rozwadowski A.

2004 Symbols through time: interpreting the Rock art of Central Asia. Poznań: Instytut Wschodni UAM, Uni-Druk.

Scott C.

1996 Music and its Secret Influence throughout the Ages. London.

Tosello G.

2006 1906-2006: un double centenaire pour Niaux at Bédeilhac. Préhistoire Art et Sociétés, 61, s. $5-10$.

Wendel H.

1964-1970 The Wendel Collection. Neanderthal Museum. 


\title{
PALAEOLITHIC PEOPLE'S WORLD OF COLOURS AS AN ELEMENT OF INTERTEXTUALITY OF „PICTURES” IN CAVES
}

\author{
S u m m a r y
}

In the article I discuss an issue of intertextuality of ,pictures” in Palaeolithic art, and of colour as its constituent. I have been inspired mainly by John Gage's works concerning colour and its significance in culture. The other important concepts appeared to be that of visual turn and that of an open and interdisciplinary approach towards an image, derived from the anthropology of images.

In my opinion, the most important issue is an ,acting" of image. However, it would be possible only if we assume an existence of ,interimaginal relations". It is legitimate when referring to prehistory, as numerous images reveal interpenetrating traces of other representations. Either consciously or unconsciously, some solutions had been used repeatedly, copying other representations, including choice of colours as a kind of stereotype deeply rooted in cultural memory. It has been acknowledged that the most important features of Palaeolithic ,pictures” were movement, colour, especially expressed by a contrast of black and red or yellow, and also an illusion.

I assume that perception of a piece of painting is influenced by stereotypes, something obvious, deeply rooted in cultural memory. It seems that already in the Palaeolithic world a spectator was important, it is why I think that this sensual approach towards ,picture” reception played a key role, as it influenced not only aesthetic perception but also cognitive abilities of humans. It should not be denied that in ,pictures" in caves colour, contrast, and shadow played a significantly important role - turning it into a tamed ,human” world, and additionally it created an illusion of a particular animal or event, and also profoundness and perspective. A spectator experiences an illusion of reality of a ,picture”, its profoundness, which influenced social perception. However, a „real” illusion, in my opinion, is an appearance of ambiguous figures, anthropomorphic (so called sorcerers from caves of Les Trois Frères and Chauvet). A particular convention might be observed in representations of animal movement, sleep, etc., repeated several times. This repetitiveness suggests that it does not result and might not result from events observed directly. Significance then is not a search of something primal, but it is being received (constructed) in a process of picture reception. It approves of an existence of a visual memory, which is a "source" knowledge of a creator and also a receiver. A spectator-researcher refers to such a visual memory.

The world of colours of contemporary people was a significant constituent of cultural meanings and of images ,,acting” in ,,mediatisation” of important contents, values and events, of existential significance, between past and present. 